\title{
Transgenic cereals: current status and future prospects
}

Article

Accepted Version

Dunwell, J. M. (2014) Transgenic cereals: current status and future prospects. Journal of Cereal Science, 59 (3). pp. 419 434. ISSN 0733-5210 doi:

https://doi.org/10.1016/j.jcs.2013.08.008 Available at https://centaur.reading.ac.uk/34327/

It is advisable to refer to the publisher's version if you intend to cite from the work. See Guidance on citing.

To link to this article DOI: http://dx.doi.org/10.1016/j.jcs.2013.08.008

Publisher: Elsevier

All outputs in CentAUR are protected by Intellectual Property Rights law, including copyright law. Copyright and IPR is retained by the creators or other copyright holders. Terms and conditions for use of this material are defined in the End User Agreement.

\section{www.reading.ac.uk/centaur}

\section{CentAUR}

Central Archive at the University of Reading

Reading's research outputs online 


\section{Accepted Manuscript}

Transgenic cereals: current status and future prospects

Jim M. Dunwell

PII: S0733-5210(13)00148-3

DOI: $\quad$ 10.1016/j.jcs.2013.08.008

Reference: $\quad$ YJCRS 1749

To appear in: Journal of Cereal Science

Received Date: 26 June 2013

Revised Date: 12 August 2013

Accepted Date: 17 August 2013

Please cite this article as: Dunwell, J.M., Transgenic cereals: current status and future prospects, Journal of Cereal Science (2013), doi: 10.1016/j.jcs.2013.08.008.

This is a PDF file of an unedited manuscript that has been accepted for publication. As a service to our customers we are providing this early version of the manuscript. The manuscript will undergo copyediting, typesetting, and review of the resulting proof before it is published in its final form. Please note that during the production process errors may be discovered which could affect the content, and all legal disclaimers that apply to the journal pertain. 
- The current commercial status of GM cereal is described

- Research on input (agronomic characteristics) and output (grain quality etc) traits is reported

- Data from global field trials are summarised

- Research trends from examination of patent databases are reported

- Public perception and regulatory issues are discussed 
3

$4 \quad$ School of Agriculture, Policy and Development, University of Reading, Earley Gate, Reading

\author{
Jim M. Dunwell
}

\section{Transgenic cereals: current status and future prospects}

RG6 6AR, UK

7

8

9 Tel: (44) 01183786313

\section{Abstract}

This review summarises the history of transgenic (GM) cereals, principally maize, and then focuses on the scientific literature published in the last two years. It describes the production of GM cereals with modified traits, divided into input traits and output traits. The first category includes herbicide tolerance and insect resistance, and resistance to abiotic and biotic stresses; the second includes altered grains for starch, protein or nutrient quality, the use of cereals for the production of high value medical or other products, and the generation of plants with improved efficiency of biofuel production. Using data from field trial and patent databases the review considers the diversity of GM lines being tested for possible future development. It also summarises the dichotomy of response to GM products in various countries, describes the basis for the varied public acceptability of such products, and assesses the development of novel breeding techniques in the light of current GM regulatory procedures. 
26

$27 \quad$ Highlights

28

29 Keywords: Genetically modified; Maize; Wheat; Barley

30 
Table of Contents

33

34

35

36

37

38

39

40

41

42

43

44

45

46

47

48

49

50

51

52

53

\section{Background}

2. Methods for production of GM plants

3. Input traits

3.1 Herbicide tolerance

3.2 Insect resistance

3.3 Pathogen tolerance

3.3.1 Fungi

3.3.2 Bacteria

3.3.3 Viruses

3.4 Abiotic stress

3.5 Yield traits

\section{Output traits}

4.1. Modified grain quality

4.1.1. Nutrition

4.2. Enzymes, diagnostics and vaccines

4.3 Biofuels

5. Pipeline of future products

5.1 Field trials

5.2 Patents 
55

56

57 6. Acceptance of GM crops

58

6.1 Regulatory aspects

59

6.2 Public perception

60

61

7. Conclusions

62

63

References 
64

65

66

67

68

8.

\section{Background}

On a global basis the cereals wheat, maize, rice, barley and sorghum are grown on almost 700 million hectares and collectively they provide approximately $40 \%$ of the energy and protein components of the human diet (Table 1). They therefore represent a vital contribution to food security both at present and also in the future when population growth (Dunwell, 2013) and other social and economic trends will require an approximate doubling of food production by 2050. Specific retrospective and prospective data for wheat yields, based on information from the Wheat initiative (www.wheatinitiative.org) are given in Table 2. In the words of the G20 Agriculture vice-ministers and deputies report from 2012 "Increasing production and productivity on a sustainable basis in economic, social and environmental terms, while considering the diversity of agricultural conditions, is one of the most important challenges that the world faces today" (http://www.g20.org/en). The UK Secretary of State for the Department for the Environment, Food and Rural Affairs made a major speech on $20^{\text {th }}$ June 2013 about the role of GM in the future of agriculture (https://www.gov.uk/government/speeches/rt-hon-owen-paterson-mp-speech-to-rothamstedresearch), and the European Academies Science Advisory Council has recently published a detailed report on the opportunities of using GM technologies in sustainable agriculture (EASAC, 2013).

Against the background of this need for increased agricultural production, this review will consider the history of genetically modified (GM) or transgenic cereals during the 30 year period since the production of the first GM plants in 1983, before discussing their present status and future potential. Information has been obtained not only from recent scientific 
89 literature but also from analysis of regulatory databases for GM crops, and from the patent 90 literature.

\section{Methods for production of GM plants}

The original method devised for the production of the first GM plants in 1983 depended on the use of the natural bacterial vector Agrobacterium tumefaciens. At that time it was assumed that this system could not be applied to cereal species and the emphasis for these crops was focussed on direct gene transfer methods, particularly the "gene-gun" or Biolistics technology. This technology was the first method successfully applied to maize. Since that time, significant improvements have been made to the Agrobacterium techniques, and these techniques can now also be applied to cereals. A recent summary of a diverse range of GM techniques is available in Dunwell and Wetten (2012).

These novel technologies include new methods for the design of constructs (Coussens et al., 2012; Karimi et al., 2013), that is the DNA sequences to be introduced and improved methods for DNA delivery. These latter methods include techniques for maize (Kirienko et al., 2012), wheat (Tamás-Nyitrai et al., 2012), rice (Duan et al., 2012b; Wakasa et al., 2012), barley (Holme et al., 2012a), triticale (Ziemienowicz et al., 2012), and tef (Eragrostis tef)

107 (Gebre et al., 2013). There is also an improved understanding of the process of regeneration 108 from plant cells in culture (Delporte et al., 2012), an important aspect of any system for high efficiency transformation.

Temporal and spatial stability of transgene expression, as well as well-defined transgene incorporation are additional features to be considered (Bregitzer and Brown, 2013; Kim and An, 2012). Likewise, it is of practical importance that GM lines can be rapidly identified, 
113

114

115

116

117

118

119

120

121

122

123

124

125

126

127

128

129

130

131

132

133

134

135

136

137

both in the laboratory (Chen et al., 2012b; Han et al., 2013b; Hensel et al., 2012; Mieog et al., 2013; Xu et al., 2013a) and under field conditions.

Another objective in many GM research projects is the development of more efficient methods for the introduction of multiple genes. These include the construction of minichromosomes in rice (Xu et al., 2012a). Additionally, there has been significant progress with efforts to induce site-specific gene integration (Nandy et al., 2012; Kapusi et al., 2012) and to use GM techniques to suppress selected genes or gene families (Wang et al., 2013b). Some of these techniques are also associated with the new techniques described below in section 5.3.

Immediately following the description of GM plants of tobacco in 1983, the commercial focus became the development of GM maize, as this crop was already hybrid and annual sales of such high-value seed was an established part of the agricultural economy of the USA and elsewhere. In contrast, the other important cereals wheat and rice are self-pollinating crops and the value of seed sales is comparatively low, and any GM variety could in theory, if not in practice, be saved by the farmer for growth in subsequent years. For this reason, there have been several attempts to convert inbreeding species into hybrid crops either through the use of chemical hybridizing agents or via GM technology. One GM approach to the production of male sterility, a necessary component of any hybrid system (Feng et al., 2013), has recently been exemplified in wheat by expressing a barnase gene (Kempe et al., 2013).

In the summaries below, the specific traits incorporated into GM varieties will be divided into those that provide advantages to the farmer/grower, the so-called input traits and those that modify the characteristics of the harvested product, the so-called output traits. 


\section{Input traits}

Prior to GM technology herbicides were classified into two categories, either selective, those that killed weeds and not crops, and non-selective, those that killed all plants. The development of selective herbicides, in particular, is a very difficult research challenge that requires an understanding of biochemical targets found only in weeds. Transgenic technology opened the possibility of converting non-selective compounds into selective ones, if a gene conferring resistance could be identified, isolated and then transferred into the crop of interest. The most obvious candidate for this strategy was glyphosate, a widely used selective herbicide marketed by Monsanto. Eventually, a bacterial resistance gene was identified and Monsanto subsequently acquired this technology, the means of introducing this gene into maize, and a company which owned elite maize inbred lines, the target for this technique. This company then had the significant commercial advantage of being able to sell both GM herbicide-tolerant (HT) varieties, and the herbicide in question. This combined approach became highly successful and provided the blueprint for many subsequent commercial programmes in maize and other crops. The second major herbicide resistant trait was that conferring tolerance to glufosinate. The commercial need for companies to be able to market both the herbicide and HT crops containing the gene conferring tolerance led to many conflicts associated with intellectual property rights (IPR) and many mergers and acquisitions. The process of consolidation of IPR began in earnest in August 1996 with AgrEvo's purchase of Plant Genetic Systems (PGS) for \$730 million, made when PGS’s 162 prior market capitalization was $\$ 30$ million. According to AgrEvo, $\$ 700$ million of the 
163

164

165

166

167

168

169

170

171

172

173

174

175

176

177

178

179

180

181

182

purchase price was assigned to the valuation of the patent-protected trait technologies (ie glufosinate resistance gene) owned by PGS (Pila, 2009). In all such cases it is important to avoid any yield drag associated with the presence of the transgene (Darmency, 2013).

At present most hybrid maize sold in the USA is resistant to one or more herbicides. The availability of such HT crops has provided the farmer with a variety of flexible options for weed control (Brookes and Barfoot, 2013a), despite some problems caused by the development of HT weeds, an issue that has stimulated the development of improved versions of glyphosate resistance genes and also of novel genes encoding resistance to other herbicides such as 2,4-D. In some regions, particularly in sub-Saharan Africa, HT maize has also provided a novel control strategy for hemi-parasitic weeds such as Striga (Ransom et al., 2012).

One novel finding in the area of HT crops is that showing the resistance of melatonin-rich GM rice plants to herbicide-induced oxidative stress (Park et al., 2013).

Monsanto also developed a glyphosate tolerant (Roundup Ready ${ }^{\mathrm{TM}}$ ) version of wheat, and carried out successful field tests in the 1990s. Due to concerns about international trade of GM wheat, this project was suspended in 2005, although recently in April 2013 some HT wheat plants carrying the Monsanto CP4 gene for glyphosate tolerance have been discovered growing in a farm in Oregon; their origin is uncertain (Fox, 2013; Ledford, 2013).

\subsection{Insect resistance}


188 The second target for GM development, together with herbicide tolerance, was insect

189

190

191

192 resistance, specifically the potential that might be provided by the toxins found in the soil bacterium Bacillus thuringiensis $(\mathrm{Bt})$. Various proteins from this bacterium were known to be toxic to a range of insects and had been used widely as sprays in agriculture and forestry since the 1950s. Improvements in molecular biology and microbiology during the 1980s meant that the genes encoding these proteins could now be isolated from various strains of the bacterium and introduced into crops. The first target was the corn borer (Ostrinia nubilalis), a lepidopteran pest of maize. Subsequently, other Bt genes were isolated; these provided resistance to other pests including the coleopteran species, corn root worm (Diabrotica spp.) (Narva et al., 2013). Present maize varieties sold in the USA have several Bt genes, usually combined with herbicide tolerance (Edgerton et al., 2012); in total there may be eight transgenes in a single variety. Recently the experience obtained from the first billion acres of Bt crops was reviewed (Tabasnik et al., 2013).

Such analysis has several aspects. One of the most important has been the need to prolong the life time of these GM varieties by avoiding the development of resistance in the target insects; the history of many insecticides suggests that resistance will eventually develop after prolonged application of any particular compound. Since the first GM products were marketed there has been advice on the need for refugia, areas of non-GM plants (Tabashnik and Gould 2012). This strategy reduces the incidence of insects carrying a mutant resistance gene in the homozygous state. As this refugia policy was not adopted by some farmers, resistant insects have indeed developed in recent years, and it is now suggested that at least five pests have developed such resistance (Tabasnik et al., 2013). Novel approaches to this issue include the combination of different Bt genes (Edwards et al., 2013), or genes with 
212 different modes of action, and the adoption of seed mixes in which Bt and non-Bt seeds are combined (Carroll et al., 2013; Zukoff et al., 2012).

214

215 Another significant environmental concern is the possibility of non-target effects, that is the 216 susceptibility of non-pest beneficial insects to the various insecticidal proteins. This is a key 217 element of all regulatory applications for sale of such products. Recent studies of this topic include those on the effects of Bt rice on a generalist spider (Tian et al., 2012) and thrips (Akhtar et al., 2013), Bt maize on bees (Dai et al., 2012) and other arthropods (Alcantera 2012; Comas et al., 2103), and the effect on aphids of GM wheat expressing a snowdrop lectin (Miao et al., 2011).

There have also been some unexpected beneficial side-effects of insect resistant crops. For example, Bt-expressing corn rootworm resistant maize has been shown to have improved nitrogen uptake and nitrogen use efficiency (Haegele and Below, 2013). These results may lead to improved agronomic practices (Bender et al., 2013). Similarly, increased microbial activity and nitrogen mineralization has also been shown in Bt maize (Velasco et al., 2013).

This contrasts with the data of Cotta et al. (2013), Lupwayi and Blackshaw (2013) and

Fließbach et al. (2013) who found no differences in the microbial communities from the rhizosphere of GM and non-GM maize, and particularly of Han et al. (2013a) who claim that Bt rice reduced the methane emission flux and the methanogenic archaeal and bacterial communities in paddy soils.

Other approaches to insect resistance include modification of the volatile emissions produced by a plant in order to deter pests or to attract beneficial insects. Such a study of GM maize expressing a terpene synthase gene showed that the costs of constitutive volatile production 
237

238

239

240

241

242

243

244

245

246

247

248

249

250

251

252

253

254

255

256

257

258

259

260

261

outweighed its benefits (Robert et al., 2013). An alternative route is to use plant-derived double-stranded RNA to target the suppression of genes essential for insect survival. This method has been shown to be effective in inhibiting growth of the Western Corn Root Worm (Diabrotica virgifera) (Bachman et al., 2013; Bolognesi et al., 2012).

\subsection{Pathogen tolerance}

\subsubsection{Fungi}

Although there are no commercial GM cereals with pathogen tolerance there has been a great deal of research on this subject, with promising results from both laboratory and field tests, particularly with wheat (http://www.isaaa.org/resources/publications/pocketk/document/DocPocket\%20K38.pdf). Wheat is affected by a number of fungal diseases such as stem rust (Puccinia graminis), Septoria, Fusarium, common bunt (Tilletia tritici) and take-all, caused by the fungus Gaeumannomyces graminis. Among these diseases, Fusarium is probably the most significant, causing crown rot and head blight that result in production of small and stunted grains or no grain at all. Some Fusarium strains also produce mycotoxins, compounds which when ingested by humans or animals may cause serious illness. These toxins, which are subject to regulation in the human food chain, can also inhibit the growth of yeast during the fermentation of cereal starch to produce bioethanol. For many years Syngenta worked on the development of a Fusarium-resistant wheat but this project was suspended in 2007, also after concerns about exports of GM wheat from the USA. Among the genes that have been shown to provide resistance to this fungus are a bovine lactoferrin gene (Han et al., 2012; Lakshman et al., 2013), an Arabidopsis thaliana NPR1 (non-expressor of PR genes) gene (Gao et al., 2013), a polygalacturonase-inhibiting protein gene from Phaseolus vulgaris (PvPGIP) (Ferrari et al., 2012) (see also Janni et al., 2013), a lipid transfer gene from wheat 
262 (Zhu et al., 2012b) and the antimicrobial peptides genes MsrA2 and 10R (Badea et al., 2013).

263 Results from this latter study showed that T3 generation GM plants had a 53\% reduction in

264 Fusarium damaged kernels, and some lines also had a 59\% reduction in powdery mildew

265 susceptibility compared with the non-GM control.

266

267 Other GM approaches to achieving mildew resistance in wheat include the use of virus-

268 induced gene silencing (VIGS) of Mlo genes (Várallyay et al., 2012), alleles of the resistance

269 locus Pm3 in wheat, conferring race-specific resistance (Brunner et al., 2012). Related studies

270 on this latter material showed that the mildew-resistant GM lines harboured bigger aphid

271 populations (Metopolophium dirhodum and Rhopalosiphum padi) than the non-transgenic

272 lines (von Burg et al., 2012). These results suggest that wheat plants that are protected from a

273 particular pest (powdery mildew) became more favourable for another pest (aphids). Other

274 evidence with the same material comes from a study of plots containing either monocultures

275 or mixtures of two GM lines (Zeller et al., 2012). It was found that resistance to mildew

276 increased with both GM richness $(0,1$, or $2 \mathrm{Pm} 3$ transgenes with different resistance

277 specificities per plot) and GM concentration $(0 \%, 50 \%$, or $100 \%$ of all plants in a plot with a

278 Pm3 transgene). Additional studies by Zeller et al. (2013) concluded that many genes

279 providing resistance against fungal pathogens demonstrate a significant cost of resistance

280 when expressed constitutively. Studies on powdery mildew in barley include one that

281 examined the effect of modifying the expression of the HvNAC6 transcription factor (Chen et

282 al., 2013).

283

284 Other recent tests have described resistance to take-all in GM wheat lines expressing an

285 R2R3-MYB gene from Thinopyrum intermedium (TiMYB2R-1) (Liu et al., 2013b) or a potato

286 antimicrobial gene (Rong et al., 2013), to Bipolaris sorokinia by expression of the related 
287

288

289

290

291

292

293

294

295

296

297

298

299

300

301

302

303

304

305

306

gene TaPIMP1 (Zhang et al., 2012d), to Penicillium seed rot in lines expressing puroindolines (Kim et al., 2012), and to rust diseases by endogenous silencing of Puccinia pathogenicity genes (Panwar et al., 2013) and expression of the Lr34 durable resistance gene (Risk et al., 2012, 2013) or TaRLP.1 (Jiang et al., 2013b). The recent discovery of the wheat Sr35 gene that confers resistance to the Ug99 strain of rust (Saintenac et al., 2013) may also provide new GM strategies to combat this disease.

Related results from rice include resistance to rice blast (Magnaporthe oryzae) in lines expressing a chimeric receptor consisting of the rice chitin oligosaccharides binding protein $(\mathrm{CEBiP})$ and the intracellular protein kinase region of Xa21 (Kouzai et al., 2013). Similarly lines expressing the WRKY30 gene showed improved resistance to rice blast and rice sheath blast (Rhizoctonia solani) (Peng et al., 2012), and lines expressing a bacterial $\alpha-1,3-$ glucanase (AGL-rice) showed strong resistance not only to the two blast pathogens but also to the phylogenetically distant ascomycete Cochlioborus miyabeanus (Fujikawa et al., 2012).

In maize silencing of a putative cystatin gene (CC9) improved resistance to the biotrophic pathogen Ustilago maydis (van der Linde et al., 2012)

\subsubsection{Bacteria}


307 It has been shown recently that silencing of the dominant allele of rice bacterial blast

308 resistance gene $\mathrm{Xa13}$ by using artificial microRNA technology generates plants highly

309 resistant to this pathogen ( $\mathrm{Li}$ et al., 2012a). These authors suggest that this approach may

310 provide a paradigm that could be adapted to other recessive resistance genes. In an alternative

311 approach, expression of $T a C P K 2-A$, a calcium-dependent protein kinase gene that is required

312 for wheat powdery mildew resistance has been shown to enhance bacterial blight resistance

313 in transgenic rice Geng et al., 2013).

\subsubsection{Viruses}

316

317

318

319

320

321

322
Projects designed to improve virus resistance in cereals include expression of an artificial microRNA to provide resistance to wheat streak mosaic virus (Fahim et al., 2012), and of a dsRNA-specific endoribonuclease gene to provide resistance to maize rough dwarf disease (MRDD) (Cao et al., 2013). It has been reported that a wheat line with resistance to yellow mosaic virus is expected to be available in the market by 2015

(http://www.isaaa.org/resources/publications/pocketk/document/Doc-Pocket\%20K38.pdf).

Related studies in rice include resistance to rice stripe disease (RSD) (caused by rice stripe virus, RSV) by expression of an RNAi construct containing the coat protein gene (CP) and disease specific protein gene (SP) sequences from RSV (Zhou et al., 2012b). A similar strategy was employed to improve resistance to the rice gall dwarf virus (RGDV) (Shimizu et al., 2012b) and rice grassy stunt virus (Shimizu et al., 2013). 
331 Following the great commercial success of herbicide tolerant and insect resistant crops,

332

333

334

335

336

337

338

339

340

341

342

343 research focus moved to the more difficult subject of tolerance to abiotic stress such as drought, salt tolerance and nitrogen and phosphate deficiency. The first commercial cereal product in this area is the Monsanto GM maize DroughtGard ${ }^{\mathrm{TM}}$ variety that expresses $\operatorname{csp} B$, an RNA chaperone gene from Bacillus subtilis (Castiglioni et al., 2008). This gene, which increases yield under water-limited conditions, is also being incorporated into maize adapted to African conditions, as part of the WEMA project (Water Efficient Maize for Africa).

There is a wide range of other approaches that are being tested at present in order to improve the growth of cereals under conditions of abiotic stress (Saint Pierre et al., 2012). For example, wheat over-expressing the 12-oxo-phytodienoic acid gene ( $T a O P R l)$ significantly enhanced the level of salinity tolerance (Dong et al., 2013). It is thought that this gene acts during episodes of abiotic stress response as a signaling compound associated with the regulation of the ABA-mediated signalling network. It is also reported that barley plants expressing the mitogen activated protein kinase HvMPK4 demonstrated improved tolerance to saline conditions (Abass and Morris, 2013).

Overexpression of a phytochrome-interacting factor-like protein, OSPIL1, in transgenic rice plants promoted internode elongation (Todaka et al., 2012). The data suggested that OsPIL1 functions as a key regulatory factor of reduced plant height via cell wall-related genes in response to drought stress and may be useful in improving plant regrowth under such conditions.

GM rice overexpressing the transcription factor OsbZIP16 exhibited significantly improved drought resistance, which was positively correlated with the observed expression levels of OsbZIP16 (Chen et al., 2012a). Related data come from studies of GM rice overexpressing 
356 Oshox22, which belongs to the homeodomain-leucine zipper (HD-Zip) family I of

357 transcription factors (Zhang et al., 2012b). These authors conclude that Oshox22 affects ABA

358 biosynthesis and regulates drought and salt responses through ABA-mediated signal

359 transduction pathways. A number of similar results have been reported by overexpression of

360 several diverse genes in GM rice. These include, OrbHLH001, a putative helix-loop-helix

361 transcription factor, that confers salt tolerance (Chen et al., 2012a); ZFP182, a TFIIIA-type

362 zinc finger protein, that significantly enhanced multiple abiotic stress tolerances, including

363 salt, cold and drought tolerances (Huang et al., 2012); OsLEA3, a Late Embryogenesis

364 Abundant protein, that showed significantly enhanced growth under saline conditions and

365 was better able to recover after 20 days of drought (Duan and Cai, 2012); a DEAD-box

366 helicase that improves growth in 200mM salt (Gill et al., 2013); and myo-inositol oxygenase

367 (MIOX), (a unique monooxygenase that catalyzes the oxidation of myo-inositol to d-

368 glucuronic acid) that improves drought tolerance by scavenging of reactive oxygenase

369 species (Duan et al., 2012a). Studies on GM rice have also suggested that overexpression of a

370 wheat gene encoding a salt-induced protein (TaSIP) (Du et al., 2013) and a sheepgrass gene

371 (LcSain1) (Li et al., 2013e) may also be of benefit in enhancing salt tolerance. An equivalent

372 investigation demonstrated that GM oats expressing the Arabidopsis $C B F 3$ gene exhibited

373 improved growth and showed significant maintenance of leaf area, chlorophyll content,

374 photosynthetic and transpiration rates, relative water content, as well as increased levels of

375 proline and soluble sugars under high salt stress (Oraby et al., 2012). At a salinity stress level

376 of $100 \mathrm{mM}$, the GM plants showed a yield loss of $4-11 \%$ compared with $>56 \%$ for the non-

377 transgenic control. According to a recent report, field trials conducted in Australia in 2009

378 (Table 3) showed that wheat lines expressing a salt tolerant gene Nax2) from Triticum

379 monococcum produced $25 \%$ more yield than the control line in saline conditions

380 http://www.isaaa.org/resources/publications/pocketk/document/Doc-Pocket\%20K38.pdf). 
382 In a similar study two wheat CBF transcription factors, TaCBF14 and TaCBF15, were

transformed into spring barley, and analysis showed that transgenic lines were able to survive

freezing temperatures several degrees lower than that which proved lethal for the wild-type

spring barley (Soltész et al., 2013). Similar results with improved frost tolerance or other

abiotic stress were achieved with GM barley expressing the rice transcription factor Osmyb4

(Soltész et al., 2011) or the wheat TaDREB3 gene (Hackenberg et al., 2012; Kovalchuk et al., 2013).

Encouraging data have also been produced from studies of GM rice overexpressing OsNAC9, a member of the rice NAC domain family (Redillas et al., 2012). Root-specific (RCc3) and constitutive (GOS2) promoters were used to overexpress OsNAC9 and field evaluations over two seasons showed that grain yields of the RCc3:OsNAC9 and the GOS2:OsNAC9 plants were increased by $13 \%-18 \%$ and $13 \%-32 \%$ under normal conditions, respectively. Under drought conditions, RCc3:OsNAC9 plants showed an increased grain yield of 28\%-72\%.

Both transgenic lines exhibited altered root architecture involving an enlarged stele and aerenchyma. One approach to the identification of genes that might confer improved drought tolerance in wheat involves use of the VIGS technique (Manmathan et al., 2013).

Studies on improving crop growth under conditions of nutritional limitation include results from the overexpression of Thellungiella halophila $\mathrm{H}^{+}$-pyrophosphatase gene in maize (Pei et al., 2012). Under phosphate sufficient conditions, GM plants showed more vigorous root growth than the wild type, and under phosphate deficit stress they also developed more robust root systems. This advantage improved phosphate uptake, and the GM plants subsequently accumulated more phosphorus. In an associated study it was found that overexpression of the 
406 phosphate transporter Phtl promoted phosphate uptake in GM rice (Sun et al., 2012). A

407 similar project concerns the use of the phosphate starvation response regulator Ta-PHR1 to

408 increase yield in wheat (Wang et al., 2013a).

409

410 One of the most ambitious of plans to improve growth under conditions of nitrogen

411 deficiency is the project to engineer nitrogen fixation into cereals. For example, the Bill \&

412 Melinda Gates Foundation is funding the ENSA (Engineering Nitrogen Symbiosis for Africa)

413 project (https://www.ensa.ac.uk/news/page/3).

415 In addition to the problems of reduced growth under conditions of nutrient deficiency, the 416 ions of certain metals inhibit normal development. One example is the inhibitory effect of 417 excess aluminium in acid soils, and this was the subject of a recent genetic study on the root 418 hairs of wheat (Delhaize et al., 2012). An alternative approach is represented by a study of 419 the multidrug and toxic compound extrusion (TaMATE1B) gene in wheat (Tovkach et al., 420 2013) and in wheat and barley (Zhou et al., 2013). One approach to improving growth in 421 alkaline soils is demonstrated by results from GM rice expressing the barley iron422 phytosiderophore transporter $(H v Y S 1)$. This gene enables barley plants to take up iron from

423 alkaline soils, and the GM rice plants grown in alkaline soil exhibited enhanced growth, yield

424 and iron concentration in leaves compared to the wild type plants which were severely

425 stunted (Gómez-Galera et al., 2012).

427 Other related recent studies include one on GM rice in which overexpression of a protein

428 disulphide isomerase-like protein from the thermophilic archaea Methanothermobacter

429 thermoautotrophicum enhances tolerance to mercury (Chen et al., 2012d) and one that 
430 demonstrated the role of the $\mathrm{Zn} / \mathrm{Cd}$ transporter OSHMA2 in cadmium accumulation in rice

431 (Takahashi et al., 2012).

432

433 3.5 Yield traits

434

The obvious aim of all the agronomic traits mentioned to date is to increase or to stabilise yield under field conditions (Shi et al., 2013). There are also future new opportunities to improve the underlying physiological performance of the plant itself. One recent example of this is investigation in rice of the major grain length QTL, qGL3, which encodes a putative protein phosphatase with a Kelch-like repeat domain (OsPPKL1). It was found that a rare allele of this gene, qg13 leads to a long grain phenotype, and transgenic studies confirmed that OsPPKL1 and OsPPKL3 function as negative regulators of grain length, whereas OsPPKL2 as a positive regulator (Zhang et al., 2012c). Grain size in rice can also be increased by overexpression of a TIFY gene, TIFY11b (Hakata et al., 2012), whereas grain number in this crop can be increased by expression of the zinc finger transcription factor DROUGHT AND

SALT TOLERANCE (DST), which itself regulates the expression of a cytokinin oxidase

Gnla/OsCKX2 (Grain number 1a/Cytokinin oxidase 2) (Li et al., 2013c). Corresponding ubiquitin ligase, in regulating grain size (Bednarek et al., 2012).

An important quality trait related to yield is the problem of post harvest sprouting. Among the

GM approaches to overcoming this problem is the use of an antisense version of the trx $s$ 
455 Amongst the most radical of research efforts are attempts to introduce the $\mathrm{C} 4$ photosynthetic 456 trait, as found in maize, into C3 cereals such as rice. This is the subject of many programmes 457 (see C4rice.irri.org). One recent report in this area is the finding that expression of the maize 458 phosphoenolpyruvate carboxylase gene in wheat increases the rate of photosynthesis in the

$459 \mathrm{GM}$ plants to $31.95 \mu \mathrm{mol} \mathrm{CO} / \mathrm{Cm}^{2} / \mathrm{s}$, some $26 \%$ greater than the rate in untransformed control 460 plants (Hu et al., 2012c). It was also found recently that constitutive expression of the rice 461 gene OsTLP27 under the control of the CaMV 35S promoter resulted in increased pigment 462 content and enhanced photochemical efficiency in terms of the values of maximal photochemical efficiency of photosystem II (PSII) $(\mathrm{F}(\mathrm{v}) / \mathrm{F}(\mathrm{m}))$, effective quantum yield of PSII (ФPSII), electron transport rate (ETR) and photochemical quenching (qP) (Hu et al., 465 2012a).

Of course, in any studies of GM cereals, as with other crops, it is always important to examine the whole plant performance, including the photosynthetic efficiency, in order to identify any non-intended effects (Sun et al., 2013).

477 Transgenic technologies provide a large variety of opportunities to modify the nutritional 478 components in cereal crops (Bhullar and Gruissem, 2013; Demont and Stein, 2013; Morell, 479 2012; Pérez-Massot et al., 2013; Rawat et al., 2013). These include modified proteins 
480 (Wenefrida et al., 2013), carbohydrate, oils, and other minor compounds and these will be

481

482

483

484

485

486

487

488

489

490

491

492

493

494

495

496

497

498

499

500

501

502

503 considered in turn.

Among the first reported GM lines of wheat were ones with modified subunits of the high molecular weight glutenin protein that confers good breadmaking quality. Recent reports in this area include the generation of GM wheat with enhancement in the concentration of highmolecular-weight glutenin subunit 1Dy10 and associated benefit in sponge and dough baking of wheat flour blends (Graybosch et al., 2013). It is also reported that such improved baking quality can be achieved without the need for selectable marker genes (Qin et al., 2013), and that coexpression of high molecular weight glutenin subunit $1 \mathrm{Ax} 1$ and puroindoline improves dough mixing properties in durum wheat (Triticum turgidum L. ssp. durum) (Li et al., 2012b). Similarly it is reported that GM methods can be used to reduce the expression of $\gamma$ gliadins and thereby potentially improve the dough mixing and bread making properties of wheat flour (Gil-Humanes et al., 2012). As part of related projects it has been shown that the starch characteristics of GM wheat overexpressing the Dx5 high molecular weight glutenin subunit are substantially equivalent to those in nonmodified wheat (Beckles et al., 2012), and that isolation of enriched gluten fractions from lines modified to overproduce HMW glutenin subunits Dx5 and/or Dy10 may require modified separation technologies (Robertson et al., 2013). Studies on the GM modification of such subunits may also lead to the production of novel proteins encoded by altered versions of either the transforming or endogenous genes (Blechl and Vensel, 2013). A relevant similar study is that on transgenic rice seed expressing the wheat HMW subunit (Oszvald et al., 2013). Another aspect of this type of study that has importance in any future regulatory submission is the determination of potential changes in the allergenicity of the GM material (Lupi et al., 2013). 
504 In addition to efforts to modify baking and bread-making quality there have also been

505 projects to modify the particular amino acid profile of cereals, in particular to increase the

506 levels of lysine. GM approaches in this area have included the expression of the $s b 401$ gene,

507 which encodes a lysine-rich protein, in GM maize; this leads to increased levels of lysine and

508 total protein in the seeds (Tang et al., 2013) (see also Wang et al., 2013c). A three generation

509 rat feeding trial of GM rice with increased levels of lysine has shown no adverse effects

510 (Zhou et al., 2012a). In a related study, expression of a bacterial serine acetyltransferase

511 (EcSAT) in rice lead to significantly higher levels of both soluble and protein-bound

512 methionine, isoleucine, cysteine, and glutathione (Nguyen et al., 2012).

514 Alongside the many projects that are designed to modify protein quantity and quality in cereals are several that focus on aspects of starch synthesis (Blennow et al., 2013). These include GM rice lines produced by introducing a cDNA for starch synthase IIa (SSIIa) from an indica cultivar (SSIIa (I), coding for active SSIIa) into an isoamylase1 (ISAl)-deficient mutant (isal) that was derived from a japonica cultivar (bearing inactive SSIIa proteins). The storage $\alpha$-glucan of these GM lines was shown to have altered solubility and crystallinity

520 (Fujita et al., 2012). Many of these projects are designed to produce products with improved health benefits. For example, using a chimeric RNAi hairpin Carciofi et al. (2012a) simultaneously suppressed all genes coding for starch branching enzymes (SBE I, SBE IIa, SBE IIb) in barley, resulting in production of amylose-only starch granules in the endosperm.

524 The authors claim that this is the first time that pure amylose has been generated with high 525 yield in a living organism, and the resulting lines with so-called "resistant starch" would have 526 potential in reducing the glycaemic index of diets. Such improvements may be of particular 527 value to diabetics and this has been shown experimentally in a study in which a high-amylose 528 GM rice, produced by inhibition of two isoforms of the starch branching enzyme, improved 
529 indices of animal health in normal and diabetic rats (Zhu et al., 2012). It was observed in a 530 similar study on GM durum wheat, in which the gene encoding one isoform of SBE was 531 silenced, that various protein differences were present in the endosperm of the transgenics 532 (Sestili et al., 2013). Rapid testing of constructs for use in such studies may be achieved by 533 using transgenic callus, rather than mature seed; this system has been developed first in 534 barley (Carciofi et al., 2012b).

535

536 GM triticale lines expressing one or both of the sucrose-sucrose 1-fructosyltransferase (1-

537 SST) gene from rye and or the sucrose-fructan 6-fructosyltransferase (6-SFT) gene from 538 wheat accumulated 50\% less starch and 10-20 times more fructan, particularly 6-kestose, in 539 the dry seed compared to the untransformed control (Diedhiou et al., 2012). This is one of the 540 first reports of GM cereals with production of fructans (Kooiker et al., 2013) in seeds.

542 An alternative route to the alteration of starch content was demonstrated by a study on GM 543 maize expressing the potato gene StSUS that encodes an isoform of sucrose synthase. Seeds 544 from these transgenic plants accumulated 10-15\% more starch at the mature stage, and 545 contained a higher amylose/amylopectin balance than the WT control seeds (Li et a., 2013a).

546 Possibly the most complex of these studies on maize was that in which the expression of six 547 genes was modified; this led to a $2.8-7.7 \%$ increase in endosperm starch and a $37.8-43.7 \%$ 548 increase in the proportion of amylose (Jiang et al., 2013a). Additionally there was a 20.1$54934.7 \%$ increase in 1000-grain weight and a 13.9-19.05\% increase in ear weight. Other 550 associated studies include the effect of the granule-bound starch synthase (GBSS), (known as 551 waxy protein), on the amylose content of GM durum wheat (Sestili et al., 2012). 
553 Among other investigations of starch biosynthetic pathway is that on the maize shrunken-2

554 (Sh2) gene, which encodes the large subunit of the rate-limiting starch biosynthetic enzyme,

555 ADP-glucose pyrophosphorylase (Tuncel and Okita, 2013). Expression in maize of a

556 transgenic form of this enzyme with enhanced heat stability and reduced phosphate inhibition

557 was shown to increase yield up to 64\% (Hannah et al., 2012). The extent of this yield increase

558 was found to be dependent on temperatures during the first 4 days post pollination, and the

559 authors also demonstrated that the transgene acts in the maternal tissue to increase seed

560 number, and thus yield.

561

562 Suppression of the CSLF6 gene in wheat has been shown to reduce the level of glucan and

563 provides an opportunity to improve the level of dietary fibre (Nemeth et al., 2010), and

564 similar suppression of glucosyl transferase genes decreases the arabinoxylan content

565 (Lovegrove et al., 2013).

566

567 GM wheat and barley with a range of modified grain traits are among the list of lines that

568 have been tested in the field in Australia (Table 3).

569

570

In the area of lipid research it has been shown that the levels of oleic acid (Zaplin et al., 2013)

571

and $\alpha$-linolenic acid (Liu et al., 2012) in rice seed can be increased by manipulation of

various fatty acid desaturase (FAD) genes.

574 Another significant area relates to vitamin and mineral content, particularly iron, with studies

575 on rice and maize summarised in Table 4. The classic example of vitamin increase is the

576 generation of "Golden Rice" (Potrykus, 2012) with higher levels of provitamin A, a

577 compound deficient in many subsistence diets based on rice. Such deficiency may lead to 
578 juvenile blindness and even death. Other recent results on modifying vitamin levels in rice

579 include expression of Arabidopsis thaliana $\rho$-hydroxyphenylpyruvate dioxygenase (HPPD),

580 which catalyzes the first committed step in vitamin E biosynthesis (Farré et al., 2012, 2013)

581 and Arabidopsis $\gamma$-tocopherol methyltransferase ( $\gamma$-TMT) (Zhang et al., 2013a), which

582 catalyzes the final step in this pathway. In a related study, Chaudhary and Khurana (2013)

583 produced GM wheat overexpressing the endogenous $H P P D$ gene and observed a 2.4 fold

584 increase in the level of tocochromomanol, one of an important group of plastidic lipophilic

585 antioxidants, which may have significant benefits in the human diet.

Results relating to iron and zinc accumulation in GM wheat expressing a ferritin gene have been discussed recently by Neal et al. (2013). In addition to increases in the levels of vitamins and minerals, GM techniques have also been used recently to improve the content of beneficial compounds such as flavonoids (Ogo et al., 2013) and sakuranetin, a flavonoid phytoalexin (Shimizu et al., 2012a) in rice. Related research demonstrating the effects of purple, anthocyanin-containing, wheat on extending the lifespan of nematodes (Chen et al., 2013b) may be developed through GM technology.

Probably the first commercial plant -derived industrial enzyme was trypsin, produced in maize kernels and marketed by Sigma (Product Code T3449) under the brand name

598 TrypZean $^{\circledR}$. This company also markets maize-derived recombinant avidin (Product Code 599 A8706). As summarised recently (Xu et al., 2012b) other recombinant products produced 600 from corn included $\beta$-glucuronidase, aprotinin and a range of degradative enzymes (also see 
601 biofuel section below). There have been significant environmental concerns expressed in the 602 USA with some of these plant derived products.

603

604 Among the most significant of GM maize products are those expressing the phytase enzyme.

605 Such products are designed to overcome the problem caused by phytate, a phosphorus

606 containing compound that is present in maize grain but one in which the phosphate is

607 unavailable to monogastric animals such as poultry and pigs and therefore causes pollution

608 from their waste. Maize expressing a phytase gene from Aspergillus niger is the first GM

609 maize to receive a biosafety certificate in China (Chen et al., 2013a) (see also Xia et al.,

610 2012). An alternative approach is to use RNAi techniques to downregulate the myo-inositol-

611 3-phosphate synthase (MIPS) gene that catalyzes the first step of phytic acid biosynthesis in

612 rice (Ali et al., 2013), or to employ cisgenic methods (Holme et al., 2012b). The value of

613 such low-phytate maize products has been recently confirmed in feeding trials with poultry

614 (Gao et al., 2012; Ma et al., 2013; Wang et al., 2013e) and pigs (Li et al., 2013d). A similar

615 benefit may derive from GM maize expressing a fungal $\beta$-mannanase from Bispora (Xu et al.,

616 2013b).

617

618 Although no GM lines in this category have yet been approved for commercialisation, there

619 has been considerable activity, over many years, in the area of plant-derived vaccines and

620 other potential pharmaceutical products. This summary describes some of the recent activity

621 in this 'pharming' area. The justification for such research lies in the assumed economic

622 benefit that might derive from using plants rather than other expression systems (eg animal

623 cells or bacteria) for production of high-value, bioactive compounds. Cereals, principally rice

624 (Greenham and Altosaar, 2012; Takaiwa, 2013), maize, and barley (Magnusdottir et al.,

625 2013) (http://www.orfgenetics.com/) have become the crops of choice, as proteins can be 
626

627

628

629

630

631

632

633

634

635

636

637

638

expressed at high levels in the seed and stored for extended periods without significant deterioration. Additionally, seed-derived antigens provide the possibility of oral delivery as an alternative to injection; this method may be of particular relevance in the area of veterinary medicine. Recent examples include the induction of a protective immune response to rabies virus in sheep after oral immunization with GM maize kernels that express the rabies virus glycoprotein (Loza-Rubio et al., 2012), and the proven immunogenicity of footand-mouth disease virus structural polyprotein P1 (Wang et al., 2012) and MOMP protein (Zhang et al., 2013a) expressed in GM rice, and the porcine reproductive and respiratory syndrome virus (PRRSV) expressed in GM maize (Hu et al., 2012b). Other similar examples are the demonstration of immunogenicity of a neutralizing epitope from porcine epidemic diarrhoea virus (PEDV) fused to an M cell-targeting ligand fusion protein and expressed in GM rice (Huy et al., 2012) and the successful production of the hepatitis B surface antigen (HBsAG) in maize (Hayden et al., 2012a,b). This latter study represents the first description of a commercially feasible oral subunit vaccine production system for a major human disease, though there has also been much publicity given to the potential of maize as a production system for an HIV neutralizing monoclonal antibody (Sabalza et al., 2012).

Recently it was confirmed that rice-derived recombinant human serum transferrin (hTF) represents a safe and animal-free alternative to human plasma-derived hTF for bioprocessing and biopharmaceutical applications (Zhang et al., 2012).

Another area of related research is that on allergens. For example, GM rice seeds have been used for the production of a recombinant hypoallergenic birch pollen allergen Bet v 1 (Wang et al., 2013d), and a hypoallergenic Der f 2 (Yang et al., 2012a) and Der p 1 (Saeki et al., 2012, 2013) derivatives of the House Dust Mite (HDM) allergen from Dermatophagoides 
651 pteronyssinus. These products may be useful in allergen-specific immunotherapy. Similarly, 652 human interleukin IL-10 (hIL-10), a therapeutic treatment candidate for inflammatory allergy 653 and autoimmune diseases, has been produced in rice seed and effectively delivered directly to 654 gut-associated lymphoreticular tissue (GALT) via bio-encapsulation (Yang et al., 2012b).

655 Related research is being conducted on the similar molecule hIL-7 (Kudo et al., 2013). Rice

656 is also the production system for human alpha-antitrypsin (AAT), a compound used as 657 therapy of individuals with mutations in the $A A T$ gene (Zhang et al., 2013b).

658

659

660

661

662

663

664

665

\subsection{Biofuels}

To date the only GM cereal with a biofuel-related trait that has been commercialised is Enogen $^{\mathrm{TM}}$, a maize hybrid expressing a thermostable alpha amylase for efficient starch hydrolysis and higher bioethanol yields. Details of this Syngenta product, which was approved by the USDA on $12^{\text {th }}$ February 2011 , are available at (http://www.syngenta.com/country/us/en/enogen/Pages/Home.aspx and http://www.syngenta.com/country/us/en/agriculture/seeds/corn/enogen/stewardship/Documen ts/June\%2014th,\%202011/Enogen\%20Overview.pdf). It is stated that ethanol throughput during fermentation with this product is increased by $5.2 \%$ and the financial benefit is between 8-15 US cents per gallon. A news item from $12^{\text {th }}$ June 2013

(http://www.agprofessional.com/news/Syngenta-footprint-for-Enogen-corn-grows-to-11ethanol-plants-211053531.html) states that a total of 11 ethanol plants in the US have now signed agreements to use this product; such plants pay the farmer an average premium of 40 cents per bushel for Enogen ${ }^{\mathrm{TM}}$ corn. Present research in Syngenta and elsewhere is also focussed on the potential for the production of recombinant cell-wall degrading enzymes in GM plants, in order to avoid the significant cost of adding exogenous enzymes during the 
676 production of fermentable sugars from biomass (Sainz, 2009). As part of this strategic goal,

677 Syngenta have signed research agreements which include those with Diversa in 2007, and

678 Verenium (now owners of Diversa) and Protéus in 2009.

679 Other relevant recent studies in this area include the production of:- bacterial

680 amylopullulanase in maize grain (Nahampun et al., 2013); thermostable xylanase in maize

681 stover (Shen et al., 2012); glycoside hydrolases (Brunecky et al., 2012); and an Acidothermus

682 cellulolyticus endoglucanase in transgenic rice seeds (Zhang et al., 2012a). Additionally,

683 down regulation of the enzyme cinnamyl alcohol dehydrogenase in maize has been shown to

684 produce a higher amount of biomass and a higher level of cellulosic ethanol in assays

685 (Fornalé et al., 2012). It is hoped that these various approaches will lead to significant

686 improvements in the efficiency of biofuel production and thereby reduce the conflict between

687 the demands for food and fuel (Zhang, 2013).

5 Pipeline of future products

690

691

\subsection{Field trials}

692

693 One simple method to assess the direction of future research on GM cereals in both

694 commercial and non-commercial programmes is to examine the various public databases that

695 summarise the applications for field testing. Such information is available from the regulatory

696 authorities in the various jurisdictions around the world. Data for the USA are available at

697 http://www.isb.vt.edu/search-release-data.aspx and can be summarised as follows:- 
698 Maize: A total of 8294 applications have been submitted in the period from 1996 to date 699 (latest $14^{\text {th }}$ June 2013). Many of these are from commercial companies and understandably 700 have limited details of the genes being tested because of Confidential Business Information

701 (CBI) restrictions. However, among the most recent application from a non-commercial 702 institution is one from the Cold Spring Harbor Laboratory that lists a total of 78 genes to be 703 tested.

704 Wheat: A total of 510 applications for have been submitted in the period from 1996 to date 705 (latest 22 $2^{\text {nd }}$ April 2013). The traits for trial in the 13 applications for 2013 include:- Nitrogen 706 use efficiency (Arcadia); Fusarium resistance (Uni. Minnesota); nitrogen metabolism, 707 drought/heat tolerance, water use efficiency, yield increase, modified flowering time, altered 708 oil content, fungal tolerance, insect resistance, herbicide tolerance (Monsanto); increased 709 carbohydrate, improved grain processing (Uni. Nebraska); herbicide tolerance (and other CBI traits) (Pioneer); and CBI traits (Biogemma); breadmaking quality (USDA).

711 Barley: a total of 109 applications were submitted in the period from 1994 to 2013 (latest

$71215^{\text {th }}$ May 2013). The traits for trial in the 6 applications for 2012 include:- starch quality

713 (USDA); nitrogen utilisation efficiency (Arcadia); Fusarium resistance (USDA); and

714 Rhizoctonia resistance (Washington State University).

Data for the EU are available at http://gmoinfo.jrc.ec.europa.eu/gmp browse.aspx and are summarised in Table 5. This list is relatively short and does not include many of the commercial trials of maize. Among the interesting trials is that testing wheat designed to have reduced levels of epitopes linked to celiac disease, and that designed to deter aphids by 719 expression of an alarm pheromone. 
721

722

723

724

725

726

727

728

729

730

731

732

733

734

735

736

737

738

739

740

741

742

743

744

745

Data from Australia are available at

http://www.ogtr.gov.au/internet/ogtr/publishing.nsf/Content/ir-1. A summary is given in

Table 3, which identifies trials of wheat and barley with modified grain traits and with various genes providing tolerance to abiotic stress. More complete detail may be obtained from the application dossiers published by the various regulatory authorities.

\subsection{Patents}

In any consideration of future trends it is of great value to assess the patent literature, as this provides a summary of those novel technologies that are the subject of research activity, particularly in commercial companies who will publish information in patent applications prior to it emerging in the conventional scientific literature. The most recent overall review of this area is that of Dunwell (2010) who includes a discussion of IPR relevant to the research scientist and to those interested in international development, globalization, and sociological and ethical aspects of the public- and private-sector relationships. Data on patent application and granted patents are available in many publically accessible databases, with the most complete being that at http://www.patentlens.net/. The extent of patent activity in the area of GM cereals is exemplified by the selection of recent US patents (Table 6a) and patent applications (Table 6b). The subject matter of these patents, taken from a short period of time, covers all the major themes discussed in this review. It is always necessary to point out the commercial reality that few, if any, of the patents and applications in these lists will ever produce a financial profit. The most common reasons for this lack of success are unexpected additional costs of development or failure of the underlying science during the transfer from laboratory to field scale. 
748 It is more than twenty years ago that the various GM regulatory legislations were enacted. For

749 example, the first iteration of the EU Directive that controls the Deliberate Release of 750 genetically modified organisms (GMOs) into the environment was adopted in 1990. The 751 foundation of this approach was to define an organism based on how it was made and the nature 752 of the resulting alterations to its genetic material. However, since that time a number of reports, 753 including the last review of the current 2001/18 Directive (EPEC, 2011), have highlighted 754 concerns about the clarity of the definition of a GMO when applying it to organisms produced 755 by particular new methodologies. These new breeding techniques (NBTs) include: 756 cisgenesis/intragenesis; site directed mutagenesis; genome editing using zinc finger nucleases, 757 TALENs (Wendt et al., 2013), CRISPRs (Shan et al., 2013) and other similar systems (Li et al., 758 2013b; Nekrasov et al., 2013); RNA dependent DNA methylation (and other epigenetic methods) (Higo et al., 2012), and reverse breeding. Reports that have considered these NBTs in more detail include that from an EU Commission Working Group on 'New Techniques', a series of papers by the Dutch committee COGEM (COGEM, 2006, 2009, 2010) and an Austrian report (Brüller et al., 2012). A report from the EU Joint Research Centre also provides useful background on the subject (Lusser et al., 2011). In principle, these techniques can be applied to any crop, including cereals. For example, there is much support in certain areas for the concept of cisgenesis, whereby the DNA introduced into recipient crop comes from a sexually compatible relative, and this method has been used to produce low-phytate barley

767 (Holme et al., 2013). In some of these methods, although molecular gene transfer techniques are used to generate the new line, there is no transgene present in the final product. Example of 769 this involve techniques for the modification of recombination or the rapid generation of mutants 
770 by suppressing the activity of DNA repair systems (Xu et al., 2012c) or generating transposon

771 induced chromosomal rearrangements (Yu et al., 2012).

772

773 Such problems of enforcement and uncertainty about whether or not new methods fall within

774 the existing legislation (Pauwels et al., 2013) has led many to argue in favour of a so-called

775 "phenotype" (or "product") based (EASAC, 2013) or "process-agnostic" system (Ammann, 776 2013).

\section{Acceptance of GM crops}

780

The commercial exploitation of GM crops varies greatly across the globe with a clear dichotomy between the position in North and South America, where such crops are grown widely, to Europe where there is little GM agriculture, though large imports of GM material for animal feed (Fresco, 2013; Masip et al., 2013). The foundation for this difference lies in a complex mixture of political, social and economic considerations. Within Europe it has been argued by some that the present regulatory impasse, whereby it has not proved possible for the 29 EU states to achieve political consensus for approval of GM crops for cultivation, should be bypassed by allowing states to determine their own policy. However, others consider this to a retrogressive approach that would lead to dangerous inconsistencies in the regulatory approach (Biszko, 2012). 
794 Before any GM product can reach the market it must receive approval from the relevant 795 regulatory authority in the appropriate legislative area. The two most important aspects of 796 such a process are food and feed safety and the potential for harm to human health and the 797 environment (Romeis et al., 2013). There is great deal of published information on these topics (eg http://www.efsa.europa.eu/en/panels/gmo.htm) and it will not be repeated here, but some of the recent information on compositional analysis has been summarised by Herman and Price (2013), Kitta (2013) and Privalle et al. (2013). Other specific recent data include information on transcriptome changes in maize expressing a phytase gene (Rao et al., 2013), tests for possible changes in allergens in GM maize (Fonseca et al., 2012) and a proteomic study on GM rice (Gong et al., 2102). Animal feeding tests (Buzoianu et al., 2013) are also a required part of any regulatory process, though the outcome of some such tests has recently provoked further controversy about GM safety (Arjó et al., 2013; Fresco, 2013) .

As regards possible environmental effects, a large-scale analysis has shown convincing evidence that one consequence of the global cultivation of GM crops has been a significant reduction both in the amount of pesticide sprayed $(\sim 8-9 \%)$ and in the release of greenhouse gas emissions from the cropping area (Brookes and Barfoot, 2013b).

812 Other environmental issues with all GM crops include possible transgene spread to wild 813 relatives (Chandler and Dunwell, 2008). Among the important variables in this context is the relative fitness of the crop-weed hybrid and this is the subject of a recent study that examined GM insect resistant rice (Yang et al., 2012c). Recent studies on GM wheat include assessment of the impact of any GM pollen transfer either within or between crops (Loureiro et al., 2012; Foetzki et al., 2012; Rieben et al., 2011). There is also discussion about the 818 possible persistence of feral populations of GM crops (Raybould et al., 2013). 
820 An interesting additional aspect relates to the possible effect of GM crops on the soil

821 microflora. This is the subject of one study on rice in which the expression of phenylalanine

822 ammonia-lyase was inhibited by RNAi methods (Fang et al., 2013). It was concluded that the

823 GM rice had less rhizospheric bacterial diversity that the non-GM control.

824

825

6.2 Public perception

826

827

828

829

830

831

832

833

834

835

836

837

838

839

840

841

842
This is a very complex area and there have been many published surveys on consumer attitudes to GM. Some of these surveys are international in scope (Frewer et al., 2013) whereas other examine attitudes in specific regions such as Europe (Ceccioli and Hixon, 2012; Gaskell et al., 2011), Switzerland (Speiser et al., 2013), Spain (Costa-Font and Gil, 2012; Rodríguez-Entrena and Sayadi, 2013) and Japan (Ishiyama et al., 2012). Among issues considered in such surveys are questions relating to basic knowledge of science (Mielby et al., 2013), ethics (Du, 2012; Gregorowius et al., 2012), human rights (Srivatava, 2013), effects on the developing world (Jacobsen and Myhr, 2013; Okeno et al., 2012), the need for choice (Mather et al., 2012), labelling (Benny, 2012), and coexistence with organic agriculture (Areal et al., 2012).

\section{Conclusions}

It remains to be seen whether the prospects and opportunities (Chen and Lin, 2013; Dunwell, 2011) described above will be translated into successful GM products in the future and whether GM technologies are compatible with sustainable (Bruce, 2012; Hansson and Joelsson, 2012) and biodiverse (Jacobsen et al., 2013) agriculture. 
844

845

846

847

848

849

850

851

852

853

854

855

856

857

858

859

860

861

862

863

864

865

866

\section{References}

Abass, M., Morris, P.C., 2013. The Hordeum vulgare signalling protein MAP kinase 4 is a regulator of biotic and abiotic stress responses. Journal of Plant Physiology doi:pii: S0176-1617(13)00186-7. 10.1016/j.jplph.2013.04.009. [Epub ahead of print]

Akhtar, Z.R., Tian, J.C., Chen, Y., Fang, Q., Hu, C., Peng, Y.F., Ye, G.Y., 2013. Impact of six transgenic Bacillus thuringiensis rice lines on four nontarget thrips species attacking rice panicles in the paddy field. Environmental Entomology 42, 173-180.

Alcantara, E.P., 2012. Postcommercialization monitoring of the long-term impact of Bt corn on non-target arthropod communities in commercial farms and adjacent riparian areas in the Philippines. Environmental Entomology 41, 1268-1276.

Ali, N., Paul, S., Gayen, D., Sarkar, S.N., Datta, S.K., Datta, K., 2013. Development of low phytate rice by RNAi mediated seed-specific silencing of inositol 1,3,4,5,6pentakisphosphate 2-kinase gene (IPK1). PLoS One. 8, e68161.

Aluru, M., Xu, Y., Guo, R. Wang Z., Li, S., White, W., Wang, K., Rodermel, S., 2008. Generation of transgenic maize with enhanced provitamin A content. Journal of Experimental Botany 59, 3551-3562.

Amara, I., Capellades, M., Ludevid, M.D., Pagès, M., Goday, A., 2013. Enhanced water stress tolerance of transgenic maize plants over-expressing LEA Rab28 gene. Journal of Plant Physiology 170, 864-873.

Ammann, K., 2013. Genomic Misconception: A fresh look at the biosafety of transgenic and conventional crops. A plea for a process agnostic regulation. New Biotechnology pii: S1871-6784(13)00060-5. doi: 10.1016/j.nbt.2013.04.008. [Epub ahead of print] 
867

868

869

870

871

872

873

874

875

876

877

878

879

880

881

882

883

884

885

886

887

888

889

890

An, N, Ou, J, Jiang, D, Zhang, L, Liu, J, Fu, K, Dai, Y, Yang, D., 2013. Expression of a functional recombinant human basic fibroblast growth factor from transgenic rice seeds. International Journal of Molecular Science 14, 3556-3567.

Areal, F.J., Riesgo, L., Gómez-Barbero, M., Rodríguez-Cerezo, E., 2012. Consequences of a coexistence policy on the adoption of GMHT crops in the European Union. Food Policy 37, 401-411.

Arjó, G., Portero, M., Piñol, C., Viñas, J., Matias-Guiu, X., Capell, T., Bartholomaeus, A., Parrott, W., Christou, P., 2013. Plurality of opinion, scientific discourse and pseudoscience: an in depth analysis of the Séralini et al. study claiming that Roundup ${ }^{\mathrm{TM}}$ Ready corn or the herbicide Roundup ${ }^{\mathrm{TM}}$ cause cancer in rats. Transgenic Research 22, 255-267.

Bachman, P.M., Bolognesi, R., Moar, W.J., Mueller, G.M., Paradise, M.S., Ramaseshadri, P., Tan, J., Uffman, J.P., Warren, J., Wiggins, B.E., Levine, S.L., 2013. Characterization of the spectrum of insecticidal activity of a double-stranded RNA with targeted activity against Western Corn Rootworm (Diabrotica virgifera virgifera LeConte). Transgenic Research DOI 10.1007/s11248-013-9716-5 [Epub ahead of print]

Badea, A., Eudes, F., Laroche, A., Graf, R., Doshi, K., Amundsen, E., Nilsson, D. and Puchalski, B., 2013. Antimicrobial peptides expressed in wheat reduce susceptibility to Fusarium head blight and powdery mildew. Canadian Journal of Plant Science 93, 199-208.

Baek, S.H., Shin, W.C., Ryu, H.S., Lee, D.W., Moon, E., Seo, C.S., Hwang, E., Lee, H.S., Ahn, M.H., Jeon, Y., Kang, H.J., Lee, S.W., Kim, S.Y., D'Souza, R., Kim, H.J., Hong, S.T., Jeon, J.S., 2013. Creation of resveratrol-enriched rice for the treatment of metabolic syndrome and related diseases. PLoS One 8, e57930. 
891

892

893

894

895

896

897

898

899

900

901

902

903

904

905

906

907

908

909

910

911

912

913

914
Bahrini, I., Ogawa, T., Kobayashi, F., Kawahigashi, H., Handa, H., 2011. Overexpression of the pathogen-inducible wheat TaWRKY45 gene confers disease resistance to multiple fungi in transgenic wheat plants. Breeding Science 61, 319-326.

Beckles, D.M., Tananuwong, K., Shoemaker, C.F., 2012. Starch characteristics of transgenic wheat (Triticum aestivum L.) overexpressing the Dx5 high molecular weight glutenin subunit are substantially equivalent to those in nonmodified wheat. Journal of Food Science 77, C437-442.

Bednarek, J., Boulaflous, A., Girousse, C., Ravel, C., Tassy, C., Barret, P., Bouzidi, M.F., Mouzeyar, S., 2012. Down-regulation of the TaGW2 gene by RNA interference results in decreased grain size and weight in wheat. Journal of Experimental Botany 63, 5945-5955.

Bender, R.B., Haegele, J.W., Ruffo, M.L., Below, F.E., 2013. Nutrient uptake, partitioning, and remobilization in modern, transgenic insect-protected maize hybrids. Agronomy Journal 105, 161-170.

Benny, E., 2012. "Natural" Modifications: The FDA's need to promulgate an official definition of "natural" that includes genetically modified organisms. The George Washington Law Review 80, 1504-574.

Bhullar, N.K., Gruissem, W., 2013.Nutritional enhancement of rice for human health: the contribution of biotechnology. Biotechnology Advances 31, 50-57.

Biszko, K.M. 2012. A house divided: exploring implications of decentralized regulation of genetically modified crops in the European Union. Georgia Journal of International \& Comparative Law 40, 527-585.

Blechl, A.E., Vensel, W.H., 2013. Variant high-molecular-weight glutenin subunits arising from biolistic transformation of wheat. Journal of Cereal Science 57, 496-503. 
915 Blennow, A., Jensen, S.L., Shaik, S.S., Skryhan, K., Carciofi, M., Holm, P.B., Hebelstrup,

916 K.H., Tanackovic, V., 2013. Future cereal starch bioengineering — Cereal

917 ancestors encounter gene-tech and designer enzymes. Cereal Chemistry 90, 274-

918 287.

919

920

921

922

923

924

925

926

927

928

929

930

931

932

933

934

935

936

937

Bolognesi, R., Ramaseshadri, P., Anderson, J., Bachman, P., Clinton, W., Flannagan, R., Ilagan, O., Lawrence, C., Levine, S., Moar, W., Mueller, G., Tan, J., Uffman, J., Wiggins, E., Heck, G., Segers, G., 2012. Characterizing the mechanism of action of double-stranded RNA activity against western corn rootworm (Diabrotica virgifera virgifera LeConte). PLoS One. 7, e47534.

Bregitzer, P., Brown, R.H., 2013. Long-term assessment of transgene behavior in barley: Dsmediated delivery of bar results in robust, stable, and heritable expression. In Vitro Cellular \& Developmental Biology - Plant 49, 231-239.

Brookes, G., Barfoot, P., 2013a. The global income and production effects of genetically modified (GM) crops 1996-2011. GM Crops and Food 4, 74-83.

Brookes, G., Barfoot, P., 2013b. Key environmental impacts of global genetically modified (GM) crop use 1996-2011. GM Crops \& Food 4, 109-119.

Bruce, T.J., 2012. GM as a route for delivery of sustainable crop protection. Journal of Experimental Botany 63, 537-541.

Brüller, W., Hartmann, J., Hochegger, R., Leonhardt, C., Mechtler, K., Peterseil, V., Ribarits, A., Söllinger, J., Stepanek, W., Widhalm, I., Wögerbauer, M., 2012. Cisgenesis. A report on the practical consequences of the application of novel techniques in plant breeding. Österreichische Agentur für Gesundheit und Ernährungssicherheit GmbH (AGES). 169 pp. 
938 Brunecky, R., Baker, J.O., Wei, H., Taylor, L.E., Himmel, M.E., Decker, S.R., 2012.

939 Analysis of transgenic glycoside hydrolases expressed in plants: T. reesei CBH I

$940 \quad$ and A. cellulolyticus EI. Methods in Molecular Biology 908, 197-211.

941 Brunner, S., Stirnweis, D., Diaz Quijano, C., Buesing, G., Herren, G., Parlange, F., Barret, P.,

942

943

944

945

946

947

948

949

950

951

952

953

954

955

956

957

958

959

960

961

962

Tassy, C., Sautter, C., Winzeler, M., Keller, B., 2012. Transgenic Pm3 multilines of wheat show increased powdery mildew resistance in the field. Plant Biotechnology Journal 10, 398-409.

Buzoianu, S.G., Walsh, M.C., Rea, M.C., Cassidy, J.P., Ryan, T.P., Ross, R.P., Gardiner G.E., Lawlor, P.G., 2013. Transgenerational effects of feeding genetically modified maize to nulliparous sows and offspring on offspring growth and health. Journal of Animal Science 91, 318-330.

Cabanos, C., Ekyo, A., Amari, Y., Kato, N., Kuroda, M., Nagaoka, S., Takaiwa, F., Utsumi, S., Maruyama, N., 2013. High-level production of lactostatin, a hypocholesterolemic peptide, in transgenic rice using soybean $\mathrm{A} 1 \mathrm{aB} 1 \mathrm{~b}$ as carrier. Transgenic Research 22, 621-629.

Cao, X., Lu, Y., Di, D., Zhang, Z., Liu, H., Tian, L., Zhang, A., Zhang, Y., Shi, L., Guo, B., Xu, J., Duan, X., Wang, X., Han, C., Miao, H., Yu, J., Li, D., 2013. Enhanced virus resistance in transgenic maize expressing a dsRNA-specific endoribonuclease gene from E. coli. PLoS One 8, e60829.

Carciofi, M., Blennow, A., Jensen, S.L., Shaik, S.S., Henriksen, A., Buléon, A., Holm, P.B., Hebelstrup, K.H., 2012a. Concerted suppression of all starch branching enzyme genes in barley produces amylose-only starch granules. BMC Plant Biology 12, 223.

Carciofi, M., Blennow, A., Nielsen, M.M., Holm, P.B., Hebelstrup, K.H., 2012b. Barley callus: a model system for bioengineering of starch in cereals. Plant Methods 8, 36 . 
963

964

965

966

967

968

969

970

971

972

973

974

975

976

977

978

979

980

981

982

983

984

985

Carroll, M.W., Head, G., Caprio, M., Stork, L., 2013. Theoretical and empirical assessment of a seed mix refuge in corn for southwestern corn borer. Crop Protection 49, 5865.

Castiglioni, P., Warner, D., Bensen, R.J., Anstrom, D.C., Harrison, J., Stoecker, M., Abad, M., Kumar, G., Salvador, S., D’Ordine, R. Navarro, S., Back, S., Fernandes, M., Targolli, J., Dasgupta, S., Bonin, C., Luethy, M.H., Heard, J.E., 2008. Bacterial RNA chaperones confer abiotic stress tolerance in plants and improved grain yield in maize under water-limited conditions. Plant Physiology 147, 446-455.

Ceccoli, S., Hixon, W., 2012. Explaining attitudes toward genetically modified foods in the European Union. International Political Science Review 33, 301-319.

Chandler, S., Dunwell, J.M., 2008. Gene flow, risk assessment and the environmental release of transgenic plants. Critical Reviews in Plant Science 27, 25-49.

Chaudhary, N., Khurana, P., 2013. Cloning, functional characterization and transgenic manipulation of vitamin E biosynthesis genes of wheat. Functional Plant Biology http://dx.doi.org/10.1071/FP12265 [in press]

Chen, H., Chen, W., Zhou, J., He, H., Chen, L., Chen, H., Deng, X.W., 2012a. Basic leucine zipper transcription factor OsbZIP16 positively regulates drought resistance in rice. Plant Science 193-194, 8-17.

Chen, H., Lin, Y., 2013. Promise and issues of genetically modified crops. Current Opinion in Plant Biology 16, 255-260.

Chen, K., Han, H., Luo, Z., Wang, Y., Wang, X., 2012b. A practicable detection system for genetically modified rice by SERS-barcoded nanosensors. Biosensors and Bioelectronics 34, 118-124. 
986

987

988

989

990

991

992

993

994

995

996

997

998

999

1000

1001

1002

1003

1004

1005

1006

1007

1008

1009

1010

Chen, R., Zhang, C., Yao, B., Xue, G., Yang, W., Zhou, X., Zhang, J., Sun, C., Chen, P., Fan, Y., 2013a. Corn seeds as bioreactors for the production of phytase in the feed industry. Journal of Biotechnology 165, 120-126.

Chen, W., Müller, D., Richling, E., Wink, M., 2013b. Anthocyanin-rich purple wheat prolongs the life span of Caenorhabditis elegans probably by activating the DAF16/FOXO transcription factor. Journal of Agricultural and Food Chemistry 61, 3047-3053.

Chen, Y., Li, F., Ma, Y., Chong, K., Xu, Y., 2012c. Overexpression of OrbHLH001, a putative helix-loop-helix transcription factor, causes increased expression of AKT1 and maintains ionic balance under salt stress in rice. Journal of Plant Physiology 170, 93-100.

Chen, Y.J., Perera, V., Christiansen, M.W., Holme, I.B., Gregersen, P.L., Grant, M.R., Collinge, D.B., Lyngkjær, M.F., 2013. The barley HvNAC6 transcription factor affects $\mathrm{ABA}$ accumulation and promotes basal resistance against powdery mildew. Plant Molecular Biology DOI 10.1007/s11103-013-0109-1 [Epub ahead of print]

Chen, Z., Pan, Y., Wang, S., Ding, Y., Yang, W., Zhu, C., 2012d. Overexpression of a protein disulfide isomerase-like protein from Methanothermobacter thermoautotrophicum enhances mercury tolerance in transgenic rice. Plant Science 197, 10-20. 0 .

Choe, Y.H., Kim, Y.S., Kim, I.S., Bae, M.J., Lee, E.J., Kim, Y.H., Park, H.M., Yoon, H.S., 2013. Homologous expression of $\gamma$-glutamylcysteine synthetase increases grain yield and tolerance of transgenic rice plants to environmental stresses. Journal of Plant Physiology 170, 610-618.

COGEM, 2006. New techniques in plant biotechnology. COGEM report CGM/061024-02. Netherlands Commission on Genetic Modification. 40 pp. 
1011 COGEM, 2009. Novel Plant Breeding Techniques. Consequences of new genetic

1012

1013

1014

1015

1016

1017

1018

1019

1020

1021

1022

1023

1024

1025

1026

1027

1028

1029

1030

1031

1032

1033

1034

1035

modification-based plant breeding techniques in comparison to conventional plant breeding. COGEM report 2009-02. Netherlands Commission on Genetic Modification. $60 \mathrm{pp}$.

COGEM, 2010. The status of oligonucleotides within the context of site-directed mutagenesis. COGEM advice and report CGM/100701-03. Netherlands Commission on Genetic Modification. 23 pp.

Comas, C., Lumbierres, B., Pons, X., Albajes, R., 2013. No effects of Bacillus thuringiensis maize on nontarget organisms in the field in southern Europe: a meta-analysis of 26 arthropod taxa. Transgenic Research DOI 10.1007/s11248-013-9737-0 [Epub ahead of print]

Cong, L., Wang, C., Chen, L., Liu, H., Yang G., He, G., 2009. Expression of phytoene synthasel and carotene desaturase crtI genes result in an increase in the total carotenoids content in transgenic elite wheat (Triticum aestivum L.). Journal of Agricultural and Food Chemistry 57, 8652-8660.

Costa-Font, M., and Gil, J.M., 2012. Meta-attitudes and the local formation of consumer judgments towards genetically modified food. British Food Journal 114, 1463-1485.

Cotta, S.R., Dias, A.C., Marriel, I.E., Gomes, E.A., van Elsas, J.D., Seldin, L., 2013. Temporal dynamics of microbial communities in the rhizosphere of two genetically modified (GM) maize hybrids in tropical agrosystems. Antonie Van Leeuwenhoek $103,589-601$.

Coussens, G., Aesaert, S., Verelst, W., Demeulenaere, M., De Buck, S., Njuguna, E., Inzé, D., Van Lijsebettens, M., 2012. Brachypodium distachyon promoters as efficient building blocks for transgenic research in maize. Journal of Experimental Botany $63,4263-4273$. 
1036

1037

1038

1039

1040

1041

1042

1043

1044

1045

1046

1047

1048

1049

1050

1051

1052

1053

1054

1055

1056

1057

1058

da Silva, L.S., Taylor, J., Taylor, J.R., 2011. Transgenic sorghum with altered kafirin synthesis: kafirin solubility, polymerization, and protein digestion. Journal of Agricultural and Food Chemistry 59, 9265-9270.

Dai, P.L., Zhou, W., Zhang, J., Cui, H.J., Wang, Q., Jiang, W.Y., Sun, J.H., Wu, Y.Y., Zhou, T., 2012. Field assessment of Bt crylAh corn pollen on the survival, development and behavior of Apis mellifera ligustica. Ecotoxicology and Environmental Safety 79, 232-237.

Darmency, H., 2013. Pleiotropic effects of herbicide-resistance genes on crop yield: a review. Pest Management Science doi: 10.1002/ps.3522. [Epub ahead of print]

Delhaize, E., James, R.A., Ryan, P.R., 2012. Aluminium tolerance of root hairs underlies genotypic differences in rhizosheath size of wheat (Triticum aestivum) grown on acid soil. New Phytologist 195, 609-619.

Delporte, F., Jacquemin, J.M., Masson, P., Watillon, B., 2012. Insights into the regenerative property of plant cells and their receptivity to transgenesis: Wheat as a research case study. Plant Signaling \& Behaviour 7, 1608-1620.

Demont, M., Stein, A.J., 2013. Global value of GM rice: a review of expected agronomic and consumer benefits. New Biotechnology 30, 426-436.

De Steur, H., Gellynck, X., Blancquaert, D., Lambert, W., Van Der Straeten, D., Qaim, M., 2012. Potential impact and cost-effectiveness of multi-biofortified rice in China. New Biotechnology 29, 432-442.

De Steur, H., Blancquaert, D., Gellynck, X., Lambert, W., Van Der Straeten, D., 2013. Exante evaluation of biotechnology innovations: the case of folate biofortified rice in China. Current Pharmaceutical Biotechnology 13, 2751-2760. 
1059 Devaiah, S.P., Requesens, D.V., Chang, Y.K., Hood, K.R., Flory, A., Howard, J.A., Hood, 1060 E.E., 2013. Heterologous expression of cellobiohydrolase II (Cel6A) in maize 1061 endosperm. Transgenic Research 22, 477-488.

1062

1063

1064

1065

1066

1067

1068

1069

1070

1071

1072

1073

1074

1075

1076

1077

1078

1079

1080

1081

1082

1083

Diedhiou, C., Gaudet, D., Liang, Y., Sun, J., Lu, Z.X., Eudes, F., Laroche, A., 2012.

Carbohydrate profiling in seeds and seedlings of transgenic triticale modified in the expression of sucrose:sucrose-1-fructosyltransferase (1-SST) and sucrose:fructan6-fructosyltransferase (6-SFT). Journal of Bioscience and Bioengineering 114, 371378.

Dong, W., Wang, M., Xu, F., Quan, T., Peng, K., Xiao, L., Xia, G., 2013. Wheat oxophytodienoate reductase gene TaOPR1 confers salinity tolerance via enhancement of abscisic acid signaling and reactive oxygen species scavenging. Plant Physiology 161, 1217-1228.

Dowd, P.F., Johnson, E.T., Price, N.P., 2012. Enhanced pest resistance of maize leaves expressing monocot crop plant-derived ribosome-inactivating protein and agglutinin. Journal of Agricultural and Food Chemistry 60, 10768-10775.

Drakakaki, G., Marcell, S., Glahn, R.P., Lund, E.K., Pariagh, S., Fischer, R., Christou, P., Stoger E., 2005. Endosperm-specific co-expression of recombinant soybean ferritin and Aspergillus phytase in maize results in significant increases in the levels of bioavailable iron. Plant Molecular Biology 59, 869-880.

Du, D., 2012. Rethinking risks: should socioeconomic and ethical considerations be incorporated into the regulation of genetically modified crops? Harvard Journal of Law \& Technology 26, 375-401.

Du, H.Y., Shen, Y.Z., Huang, Z.J., 2013. Function of the wheat TaSIP gene in enhancing drought and salt tolerance in transgenic Arabidopsis and rice. Plant Molecular Biology 81, 417-429. 
Duan, J., Cai, W., 2012. OsLEA3-2, an abiotic stress induced gene of rice plays a key role in salt and drought tolerance. PLoS One 7, e45117.

Duan, J., Zhang, M., Zhang, H., Xiong, H., Liu, P., Ali, J., Li, J., Li, Z., 2012a. OsMIOX, a myo-inositol oxygenase gene, improves drought tolerance through scavenging of reactive oxygen species in rice (Oryza sativa L.). Plant Science 196, 143-151.

Duan, Y., Zhai, C., Li, H., Li, J., Mei, W., Gui, H., Ni, D., Song, F., Li, L., Zhang, W., Yang, J., 2012b. An efficient and high-throughput protocol for Agrobacterium-mediated transformation based on phosphomannose isomerase positive selection in Japonica rice (Oryza sativa L.). Plant Cell Reports 31, 1611-1624.

Dunwell, J.M., 2008. Transgenic wheat, barley and oats: future prospects. In: Jones, H.D., Shewry, P.R., (Eds.), Transgenic Wheat, Barley and Oats: Production and Characterisation, Methods in Molecular Biology, vol 478. Humana Press. pp. 333345.

Dunwell, J.M., 2010. Patent and intellectual property rights issues. In: Kole, C., Michler, C.H., Abbott, A.G., Hall, T.C., (Eds.), Transgenic Crop Plants. Volume 2: Utilization and Biosafety, Springer-Verlag, Berlin, Heidelberg, New York. pp. 411433.

Dunwell, J.M., 2011. Crop biotechnology: prospects and opportunities. Journal of Agricultural Science 149, 17-27.

Dunwell, J.M. and Wetten, A.C. eds., 2012. Transgenic Plants. Methods and Protocols. Methods in Molecular Biology 847. Humana Press. 497 pp.

Dunwell, J.M., 2013. Global population growth, food security and food and farming for the future. In: Bennett, D.J., Jennings, R.C., (Eds.), Successful Agricultural Innovation in Emerging Economies: New Genetic Technologies for Global Food Production, Cambridge University Press. pp. 23-38. 
1109 EASAC, 2013. Planting the Future: Opportunities and Challenges for Using Crop Genetic

1110

1111

1112 Improvement Technologies for Sustainable Agriculture. EASAC policy report 21, www.easac.eu, ISBN 978-3-8047-3181-3, 78 pp.

Edgerton, M.D., Fridgen, J., Anderson, J.R. Jr, Ahlgrim, J., Criswell, M., Dhungana, P., Gocken, T., Li, Z., Mariappan, S., Pilcher, C.D., Rosielle, A., Stark, S.B., 2012. Transgenic insect resistance traits increase corn yield and yield stability. Nature Biotechnology 30, 493-496.

Edwards, K.T., Caprio, M.A., Allen, K.C., Musser, F.R., 2013. Risk assessment for Helicoverpa zea (Lepidoptera: Noctuidae) resistance on dual-gene versus singlegene corn. Journal of Economic Entomology 106, 382-392.

EPEC, 2011. Evaluation of the EU legislative framework in the field of cultivation of GMOs under directive 2001/18/EC and regulation (EC) No 1829/2003, and the placing on the market of GMOs as or in products under directive 2001/18/EC. European Policy Evaluation Consortium. 137 pp.

Fahim, M., Millar, A.A., Wood, C.C., Larkin, P.J., 2012. Resistance to Wheat streak mosaic virus generated by expression of an artificial polycistronic microRNA in wheat. Plant Biotechnology Journal 10, 150-63.

Fang, C., Zhuang, Y., Xu, T., Li, Y., Li, Y., Lin, W., 2013. Changes in rice allelopathy and rhizosphere microflora by inhibiting rice phenylalanine ammonia-lyase gene expression. Journal of Chemical Ecology 39, 204-212.

Farré, G., Sudhakar, D., Naqvi, S., Sandmann, G., Christou, P., Capell, T., Zhu, C., 2012. Transgenic rice grains expressing a heterologous $\rho$-hydroxyphenylpyruvate dioxygenase shift tocopherol synthesis from the $\gamma$ to the $\alpha$ isoform without increasing absolute tocopherol levels. Transgenic Research 21, 1093-1097. 
1133 Farré, G., Naqvi, S., Zorrilla-López, U., Sanahuja, G., Berman, J., Sandmann, G., Ros, G.,

1134

1135

1136

1137

1138

1139

1140

1141

1142

1143

1144

1145

1146

1147

1148

1149

1150

1151

1152

1153

1154

1155

1156

1157

López-Nicolás, R., Twyman, R.M., Christou, P., Capell, T., Zhu, C., 2013. Transgenic

multivitamin biofortified corn: science, regulation, and politics. Handbook of Food

Fortification and Health Nutrition and Health, pp. 335-347.

Feng, P.C., Qi, Y., Chiu, T., Stoecker, M.A., Schuster, C.L., Johnson, S.C., Fonseca, A.E., Huang, J. 2013. Improving hybrid seed production in corn with glyphosatemediated male sterility. Pest Management Science doi: 10.1002/ps.3526. [Epub ahead of print]

Ferrari, S., Sella, L., Janni, M., De Lorenzo, G., Favaron, F., D'Ovidio, R., 2012. Transgenic expression of polygalacturonase-inhibiting proteins in Arabidopsis and wheat increases resistance to the flower pathogen Fusarium graminearum. Plant Biology 14 Suppl 1, 31-38.

Fließbach, A., Nietlispach, B., Messmer, M., Rodríguez-Romero, A-S., Mäder, P., 2013. Microbial response of soils with organic and conventional management history to the cultivation of Bacillus thuringiensis (Bt)-maize under climate chamber conditions. Biology and Fertility of Soils DOI: 10.1007/s00374-013-0776-8

Foetzki, A., Quijano, C.D., Moullet, O., Fammartino, A., Kneubuehler, Y., Mascher, F., Sautter, C., Bigler, F., 2012. Surveying of pollen-mediated crop-to-crop gene flow from a wheat field trial as a biosafety measure. GM Crops \& Food 3, 115-122.

Fonseca, C., Planchon, S., Renaut, J., Oliveira, M.M., Batista, R., 2012. Characterization of maize allergens - MON810 vs. its non-transgenic counterpart. Journal of Proteomics $75,2027-2037$.

Fornalé, S., Capellades, M., Encina, A., Wang, K., Irar, S., Lapierre, C., Ruel, K., Joseleau, J.P., Berenguer, J., Puigdomènech, P., Rigau, J., Caparrós-Ruiz, D., 2012. Altered lignin biosynthesis improves cellulosic bioethanol production in transgenic maize 
plants down-regulated for cinnamyl alcohol dehydrogenase. Molecular Plant 5, 817830.

Fox, J.L., 2013. Volunteer GM wheat, mischief or carelessness? Nature Biotechnology 31, 669670.

Fresco, L.O., 2013. The GMO stalemate in Europe. Science 339, 883.

Frewer, L.J., van der Lans, I.A., Fischer, A.R.H., Reinders, M.J., Menozzi, D., Zhang, X., van den Berg, I., Zimmermann, K.L., 2013. Public perceptions of agri-food applications of genetic modification - A systematic review and meta-analysis. Trends in Food Science \& Technology 30, 142-152.

Fujikawa, T., Sakaguchi, A., Nishizawa, Y., Kouzai, Y., Minami, E., Yano, S., Koga, H., Meshi, T., Nishimura, M., 2012. Surface $\alpha$-1,3-glucan facilitates fungal stealth infection by interfering with innate immunity in plants. PLoS Pathogens 8 , e1002882.

Fujita, N., Hanashiro, I., Suzuki, S., Higuchi, T., Toyosawa, Y., Utsumi, Y., Itoh, R., Aihara, S., Nakamura, Y., 2012. Elongated phytoglycogen chain length in transgenic rice endosperm expressing active starch synthase IIa affects the altered solubility and crystallinity of the storage $\alpha$-glucan. Journal of Experimental Botany 63, 58595872.

Gao, C.Q., Ma, Q.G., Ji, C., Luo, X.G., Tang, H.F., Wei, Y.M., 2012. Evaluation of the compositional and nutritional values of phytase transgenic corn to conventional corn in roosters. Poultry Science 91, 1142-1148.

Gao, C.-S., Kou, X.-J., Li, H.-P., Zhang, J.-B., Saad, A.S.I., Y.-C. Liao, Y.-C., 2013. Inverse effects of Arabidopsis NPR1 gene on fusarium seedling blight and fusarium head blight in transgenic wheat. Plant Pathology 62, 383-392. 
1182

1183

1184

1185

1186

Gaskell G, Allansdottir A, Allum N, Castro P, Esmer Y, Fischler C, Jackson J, Kronberger N, Hampel J, Mejlgaard N, Quintanilha A, Rammer A, Revuelta G, Stares S, Torgersen H and Wager W., 2011. The 2010 Eurobarometer on the life sciences. Nature Biotechnology 29, 113-114.

Gayen, D., Sarkar, S.N., Datta, S.K., Datta, K., 2013. Comparative analysis of nutritional compositions of transgenic high iron rice with its non-transgenic counterpart. Food Chemistry $138,835-840$.

Gebre, E., Gugsa, L., Schlüter, U., Kunert, K., 2013. Transformation of tef (Eragrostis tef) by Agrobacterium through immature embryo regeneration system for inducing semidwarfism. South African Journal of Botany 87, 9-17

Geng, S., Li, A., Tang, L., Yin, L., Wu, L., Lei, C., Guo, X., Zhang, X., Jiang, G., Zhai, W., Wei, Y., Zheng, Y., Lan, X., Mao, L., 2013. TaCPK2-A, a calcium-dependent protein kinase gene that is required for wheat powdery mildew resistance enhances bacterial blight resistance in transgenic rice. Journal of Experimental Botany 64, $3125-3136$.

Gil-Humanes, J., Pistón, F., Giménez, M.J., Martín, A., Barro, F, 2102. The introgression of RNAi silencing of $\gamma$-gliadins into commercial lines of bread wheat changes the mixing and technological properties of the dough. PLoS One 7, e45937.

Gill, S.S., Tajrishi, M., Madan, M., Tuteja, N., 2013. A DESD-box helicase functions in salinity stress tolerance by improving photosynthesis and antioxidant machinery in rice (Oryza sativa L. cv. PB1). Plant Molecular Biology 82, 1-22.

Gómez-Galera, S., Sudhakar, D., Pelacho, A.M., Capell, T., Christou, P., 2012. Constitutive expression of a barley Fe phytosiderophore transporter increases alkaline soil tolerance and results in iron partitioning between vegetative and storage tissues under stress. Plant Physiology and Biochemistry 53, 46-53. 
1207 Gong, C.Y., Li, Q., Yu, H.T., Wang, Z., Wang, T., 2012. Proteomics insight into the

1208

1209

1210

1211

1212

1213

1214

1215

1216

1217

1218

1219

1220

1221

1222

1223

1224

1225

1226

1227

1228

1229

1230 biological safety of transgenic modification of rice as compared with conventional genetic breeding and spontaneous genotypic variation. Journal of Proteome Research 11, 3019-3029.

Graybosch, R.A., Seabourn, B., Chen, Y.R., Blechl, A.E., 2013. Transgenic enhancement of high-molecular-weight glutenin subunit 1Dy10 concentration: effects in wheat flour blends and sponge and dough baking. Cereal Chemistry 90, 164-168.

Greenham, T., Altosaar, I., 2012. Molecular strategies to engineer transgenic rice seed compartments for large-scale production of plant-made pharmaceuticals. Methods in Molecular Biology 956:311-326.

Gregorowius, D., Lindemann-Matthies, P., Huppenbauer, M., 2012. Ethical discourse on the use of genetically modified crops: a review of academic publications in the fields of ecology and environmental ethics. Journal of Agricultural and Environmental Ethics $25,265-293$.

Guo, H., Zhang, H., Li, Y., Ren, J., Wang, X., Niu, H., Yin, J., 2011. Identification of changes in wheat (Triticum aestivum L.) seeds proteome in response to Anti-trx $s$ gene. PLoS ONE 6(7): e22255.

Hackenberg, M., Shi, B.J., Gustafson, P., Langridge, P., 2012. A transgenic transcription factor (TaDREB3) in barley affects the expression of microRNAs and other small non-coding RNAs. PLoS One 7, e42030

Haegele, J.W., Below, F.E., 2013. Transgenic corn rootworm protection increases grain yield and nitrogen use of maize. Crop Science 53, 585-594.

Hakata, M., Kuroda, M., Ohsumi, A., Hirose, T., Nakamura, H., Muramatsu, M., Ichikawa, H., Yamakawa, H., 2012. Overexpression of a rice TIFY gene increases grain size 
through enhanced accumulation of carbohydrates in the stem. Bioscience Biotechnology and Biochemistry 76, 2129-2134.

Han, C., Zhong, W., Shen, W., Cai, Z., Liu, B., 2013a. Transgenic Bt rice has adverse impacts on $\mathrm{CH}_{4}$ flux and rhizospheric methanogenic archaeal and methanotrophic bacterial communities. Plant and Soil 369, 297-316.

Han, J., Lakshman, D.K., Galvez, L.C., Mitra, S., Baenziger, P.S., Mitra, A., 2012.

Transgenic expression of lactoferrin imparts enhanced resistance to head blight of wheat caused by Fusarium graminearum. BMC Plant Biology 12, 33.

Han, X., Wang, H., Chen, H., Mei, L., Wu, S., Jia, G., Cheng, T., Zhu, S., Lin, X., 2013b. Development and primary application of a fluorescent liquid bead array for the simultaneous identification of multiple genetically modified maize. Biosensors and Bioelectronics 49, 360-366.

Hannah, L.C., Futch, B., Bing, J., Shaw, J.R., Boehlein, S., Stewart, J.D., Beiriger, R., Georgelis, N., Greene, T., 2012. A shrunken-2 transgene increases maize yield by acting in maternal tissues to increase the frequency of seed development. Plant Cell $24,2352-2363$.

Hansson, S.O., Joelsson, K., 2012. Crop biotechnology for the environment? Journal of Agricultural and Environmental Ethics DOI 10.1007/s10806-012-9405-z [in press]

Harwood, W.A., 2012. Advances and remaining challenges in the transformation of barley and wheat. Journal of Experimental Botany 63, 1791-1798.

Hayden, C.A., Egelkrout, E.M., Moscoso, A.M., Enrique, C., Keener, T.K., Jimenez-Flores, R., Wong, J.C., Howard, J.A., 2012a. Production of highly concentrated, heat-stable hepatitis B surface antigen in maize. Plant Biotechnology Journal 10, 979-984.

Hayden, C.A, Streatfield, S.J., Lamphear, B.J., Fake, G.M., Keener, T.K., Walker, J.H., Clements, J.D., Turner, D.D., Tizard, I.R., Howard, J.A., 2012b. Bioencapsulation 
1256

1257

1258

1259

1260

1261

1262

1263

1264

1265

1266

1267

1268

1269

1270

1271

1272

1273

1274

1275

1276

1277

1278

1279

1280

of the hepatitis B surface antigen and its use as an effective oral immunogen. Vaccine 30, 2937-2942.

Helliwell, E.E., Wang, Q., Yang, Y., 2013. Transgenic rice with inducible ethylene production exhibits broad-spectrum disease resistance to the fungal pathogens Magnaporthe oryzae and Rhizoctonia solani. Plant Biotechnology Journal 11, 3342.

Hensel, G., Oleszczuk, S., Daghma, D.E., Zimny, J., Melzer, M., Kumlehn, J., 2012. Analysis of T-DNA integration and generative segregation in transgenic winter triticale $(x$ Triticosecale Wittmack). BMC Plant Biology 12, 171.

Herman, R.A., Price, W.D., 2013. Unintended compositional changes in genetically modified (GM) crops: 20 years of research. Journal of Agricultural and Food Chemistry. DOI: $10.1021 /$ jf400135r [Epub ahead of print]

Higo, H., Tahir, M., Takashima, K., Miura, A., Watanabe, K., Tagiri, A., Ugaki, M., Ishikawa, R., Eiguchi, M., Kurata, N., Sasaki, T., Richards, E., Takano, M., Kishimoto, N., Kakutani, T., Habu Y., 2012. DDM1 (Decrease in DNA Methylation) genes in rice (Oryza sativa). Molecular Genetics and Genomics 287, 785-792.

Holme, I.B., Brinch-Pedersen, H., Lange, M., Holm, P.B., 2012a. Transformation of barley (Hordeum vulgare L.) by Agrobacterium tumefaciens infection of in vitro cultured ovules. Methods in Molecular Biology 847, 151-161.

Holme, I.B., Dionisio, G., Brinch-Pedersen, H., Wendt, T., Madsen, C.K., Vincze, E. Holm, P.B., 2012b. Cisgenic barley with improved phytase activity. Plant Biotechnology Journal 10, 237-247.

Holme, I.B., Wendt, T., Holm, P.B., 2013. Intragenesis and cisgenesis as alternatives to transgenic crop development. Plant Biotechnology Journal 11, 395-407. 
1281

1282

1283

1284

1285

1286

1287

1288

1289

1290

1291

1292

1293

1294

1295

1296

1297

1298

1299

1300

1301

1302

1303

Hood, E.E., Devaiah, S.P., Fake, G., Egelkrout, E., Teoh, K.T., Requesens, D.V., Hayden, C., Hood, K.R., Pappu, K.M., Carroll, J., Howard, J.., 2012. Manipulating corn germplasm to increase recombinant protein accumulation. Plant Biotechnol Journal 10, 20-30.

Hu, F., Kang, Z., Qiu, S., Wang, Y., Qin, F., Yue, C., Huang, J., Wang, G., 2012a. Overexpression of $O s T L P 27$ in rice improves chloroplast function and photochemical efficiency. Plant Science 195, 125-134.

Hu, J., Ni Y., Dryman, B.A., Meng, X.J., Zhang, C., 2012b. Immunogenicity study of plantmade oral subunit vaccine against porcine reproductive and respiratory syndrome virus (PRRSV). Vaccine 30, 2068-2074.

Hu, L., Li, Y., Xu, W., Zhang, Q., Zhang, L., Qi, X., Dong, H., 2012c. Improvement of the photosynthetic characteristics of transgenic wheat plants by transformation with the maize $\mathrm{C}_{4}$ phosphoenolpyruvate carboxylase gene. Plant Breeding 131, 385-391.

Huang, J., Sun, S., Xu, D., Lan, H., Sun, H., Wang, Z., Bao, Y., Wang, J., Tang, H., Zhang, H., 2012. A TFIIIA-type zinc finger protein confers multiple abiotic stress tolerances in transgenic rice (Oryza sativa L.). Plant Molecular Biology 80, 337350.

Huang, X., Wang, J., Du, Z., Zhang, C., Li, L., Xu, Z., 2013. Enhanced resistance to stripe rust disease in transgenic wheat expressing the rice chitinase gene RC24. Transgenic Research DOI: 10.1007/s11248-013-9704-9 [Epub ahead of print]

Huy, N.X., Kim, S.H., Yang, M.S., Kim, T.G., 2012. Immunogenicity of a neutralizing epitope from porcine epidemic diarrhea virus: $M$ cell targeting ligand fusion protein expressed in transgenic rice calli. Plant Cell Reports 31, 1933-1942. 
1304 Ignacimuthu, S., Ceasar, S.A., 2912. Development of transgenic finger millet (Eleusine

1305

1306

1307

1308

1309

1310

1311

1312

1313

1314

1315

1316

1317

1318

1319

1320

1321

1322

1323

1324

1325

1326

1327

1328 coracana (L.) Gaertn.) resistant to leaf blast disease. Journal of Bioscience 37, 135147.

Ishiyama, I., Tanzawa, T., Watanabe, M., Maeda, T., Muto, K., Tamakoshi, A., Nagai, A., Yamagata, Z., 2012. Public attitudes to the promotion of genomic crop studies in Japan: Correlations between genomic literacy, trust, and favourable attitude. Public Understanding of Science 21, 495-512.

Jacobson, K., Myhr, A.I., 2013. GM crops and smallholders: biosafety and local practice. The Journal of Environment Development 22, 104-124.

Jacobsen, S-E., Sørensen, M., Pedersen, S.M., Weiner, J., 2013. Feeding the world: genetically modified crops versus agricultural biodiversity. Agronomy for Sustainable Development DOI 10.1007/s13593-013-0138-9 [in press]

Janni, M., Bozzini, T., Moscetti, I., Volpi, C., D'Ovidio, R., 2013. Functional characterisation of wheat Pgip genes reveals their involvement in the local response to wounding. Plant Biology DOI: 10.1111/plb.12002 [in press]

Jeong, J.S., Kim, Y.S., Redillas, M.C., Jang, G., Jung, H., Bang, S.W., Choi, Y.D., Ha, S.H., Reuzeau, C., Kim, J.K., 2013. OsNAC5 overexpression enlarges root diameter in rice plants leading to enhanced drought tolerance and increased grain yield in the field. Plant Biotechnology Journal 11, 101-114.

Jiang, L., Yu, X., Qi, X., Yu, Q., Deng, S., Bai, B., Li, N., Zhang, A., Zhu, C., Liu, B., Pang, J., 2013a. Multigene engineering of starch biosynthesis in maize endosperm increases the total starch content and the proportion of amylose. Transgenic Research DOI 10.1007/s11248-013-9717-4 [Epub ahead of print]

Jiang, Z., Ge, S., Xing, L., Han, D., Kang, Z., Zhang, G., Wang, X., Wang, X., Chen, P., Cao, A., 2013b. RLP1.1, a novel wheat receptor-like protein gene, is involved in the 
defence response against Puccinia striiformis f. sp. tritici. Journal of Experimental Botany doi: 10.1093/jxb/ert206 [Epub ahead of print]

Johnson, A.A.T., Kyriacou, B., Callahan, D.L., Carruthers, L., Stangoulis, J., Lombi, E., Tester, M., 2011. Constitutive overexpression of the OsNAS gene family reveals single-gene strategies for effective iron- and zinc-biofortification of rice endosperm. PLOS One 6, e24476.

Kapusi, E., Kempe, K., Rubtsova, M., Kumlehn, J., Gils, M., 2012. phiC31 integrasemediated site-specific recombination in barley. PLoS One 7, e45353.

Karimi, M., Inzé, D., Van Lijsebettens, M., Hilson, P., 2013. Gateway vectors for transformation of cereals. Trends in Plant Science 18, 1-4.

Kempe, K., Rubtsova, M., Riewe, D., Gils, M., 2013. The production of male-sterile wheat plants through split barnase expression is promoted by the insertion of introns and flexible peptide linkers. Transgenic Research DOI 10.1007/s11248-013-9714-7 [in press]

Kim, K-H., Feiz, L., Dyer, A.T., Grey, W., Hogg, A.C., Martin, J.M., Giroux,, M.J., 2012. Increased resistance to Penicillium seed rot in transgenic wheat over-expressing puroindolines. Journal of Phytopathology 160, 243-247.

Kim, S.R., An, G., 2012. Bacterial transposons are co-transferred with T-DNA to rice chromosomes during Agrobacterium-mediated transformation. Molecules and Cells $33,583-589$.

Kim, T.G., Kim, M.Y., Huy, N.X., Kim, S.H., Yang, M.S., 2013a. M cell-targeting ligand and consensus dengue virus envelope protein domain III fusion protein production in transgenic rice calli. Molecular Biotechnology 54, 880-887.

Kim, Y.S., Kim, I.S., Bae, M.J., Choe, Y.H., Kim, Y.H., Park, H.M., Kang, H.G., Yoon, H.S., 2013b. Homologous expression of cytosolic dehydroascorbate reductase 
1354

1355

1356

1357

1358

1359

1360

1361

1362

1363

1364

1365

1366

1367

1368

1369

1370

1371

1372

1373

1374

1375

1376

increases grain yield and biomass under paddy field conditions in transgenic rice (Oryza sativa L. japonica). Planta 237, 1613-1625.

Kirienko, D.R., Luo, A., Sylvester, A.W., 2012. Reliable transient transformation of intact maize leaf cells for functional genomics and experimental study. Plant Physiology $159,1309-1318$.

Kitta, K., 2013. Availability and utility of crop composition data. Journal of Agricultural and Food Chemistry DOI: 10.1021/jf400777v [Epub ahead of print]

Klose, H., Günl, M., Usadel, B., Fischer, R., Commandeur, U., 2013. Ethanol inducible expression of a mesophilic cellulase avoids adverse effects on plant development. Biotechnology for Biofuels 6, 53.

Kooiker, M., Drenth, J., Glassop, D., McIntyre, C.L., Xue, G.P., 2013. TaMYB13-1, a R2R3 MYB transcription factor, regulates the fructan synthetic pathway and contributes to enhanced fructan accumulation in bread wheat. Journal of Experimental Botany doi: 10.1093/jxb/ert205 [Epub ahead of print]

Kouzai, Y., Kaku, H., Shibuya, N., Minami, E., Nishizawa, Y., 2013. Expression of the chimeric receptor between the chitin elicitor receptor CEBiP and the receptor-like protein kinase Pi-d2 leads to enhanced responses to the chitin elicitor and disease resistance against Magnaporthe oryzae in rice. Plant Molecular Biology 81, 287295.

Kovalchuk, N., Jia, W., Eini, O., Morran, S., Pyvovarenko, T., Fletcher, S., Bazanova, N., Harris, J., Beck-Oldach, K., Shavrukov, Y., Langridge, P., Lopato, S., 2013. Optimization of TaDREB3 gene expression in transgenic barley using coldinducible promoters. Plant Biotechnology Journal 11, 659-670. 
Kudo, K., Ohta, M., Yang, L., Wakasa, Y., Takahashi, S., Takaiwa, F., 2013. ER stress response induced by the production of human IL-7 in rice endosperm cells. Plant Molecular Biology 81, 461-475.

Kumar, T., Dweikat, I., Sato, S., Ge, Z., Nersesian, N., Chen, H., Elthon, T., Bean, S., Ioerger, B.P., Tilley, M., Clemente, T., 2013. Modulation of kernel storage proteins in grain sorghum (Sorghum bicolor (L.) Moench). Plant Biotechnology Journal 10, 533-544.

Kwon, J.Y., Yang, Y.S., Cheon, S.H., Nam, H.J., Jin, G.H., Kim, D.I., 2013. Bioreactor engineering using disposable technology for enhanced production of hCTLA4Ig in transgenic rice cell cultures. Biotechnology and Bioengineering 110, 2412-2424.

Lakshman, D.K., Natarajan, S., Mandal, S., Mitra, A., 2013. Lactoferrin derived resistance against plant pathogens in transgenic plants. Journal of Agricultural and Food Chemistry DOI: 10.1021/jf400756t [Epub ahead of print]

Lee, S., Jeon, U.S., Lee, S.J., Kim, Y.K., Persson, D.P. Husted, S., Schjørring, J.K., Kakei, Y., Masuda, H., Nishizawa, N.K., An, G., 2009. Iron fortification of rice seeds through activation of the nicotianamine synthase gene. Proceedings of the National Academy of Sciences of the United States of America 106, 22014-22019.

Lee, S., Persson, D.P., Hansen, T.H., Husted, S., Schjoerring, J.K., Kim, Y.S., Jeon, U.S., Kim, Y.K., Kakei, Y., Masuda, H., Nishizhawa, N.K., An, G., 2011. Bio-available zinc in rice seeds is increased by activation tagging of nicotianamine synthase. Plant Biotechnology Journal 9, 865-873.

Ledford, H., 2013. Hunt for mystery GM wheat hots up. Nature 499, 262-263.

Li, C., Wei, J., Lin, Y., Chen, H., 2012a. Gene silencing using the recessive rice bacterial blight resistance gene $x a 13$ as a new paradigm in plant breeding. Plant Cell Reports $31,851-862$ 
1402

1403

1404

1405

1406

1407

1408

1409

1410

1411

1412

1413

1414

1415

1416

1417

1418

1419

1420

1421

1422

1423

1424

1425

Li, J., Baroja-Fernández, E., Bahaji, A., Muñoz, F.J., Ovecka, M., Montero, M., Sesma, M.T., Alonso-Casajús, N., Almagro, G., Sánchez-López, A.M., Hidalgo, M., Zamarbide, M., Pozueta-Romero, J., 2013a. Enhancing sucrose synthase activity results in increased levels of starch and ADP-glucose in maize (Zea mays L.) seed endosperms. Plant \& Cell Physiology 54, 282-294.

Li, J-F., Norville, J.E., Aach, J., McCormack, M., Zhang, D., Bush, J., Church, G.M., Sheen, J., 2013b. Multiplex and homologous recombination-mediated genome editing in Arabidopsis and Nicotiana benthamiana using guide RNA and Cas9. Nature Biotechnology 31, 688-691.

Li, S., Zhao, B., Yuan, D., Duan, M., Qian, Q., Tang, L., Wang, B., Liu, X., Zhang, J., Wang, J., Sun, J., Liu, Z., Feng, Y.Q., Yuan, L., Li, C., 2013c. Rice zinc finger protein DST enhances grain production through controlling Gn1a/OsCKX2 expression. Proceedings of the National Academy of Sciences of the United States of America $110,3167-3172$.

Li, S.F., Niu, Y.B., Liu, J.S., Lu, L., Zhang, L.Y., Ran, C.Y., Feng, M.S., Du, B., Deng, J.L., Luo, X.G., 2013d. Energy, amino acid, and phosphorus digestibility of phytase transgenic corn for growing pigs. Journal of Animal Science 91, 298-308.

Li, X., Hou, S., Gao, Q., Zhao, P., Chen, S., Qi, D., Lee, B.H., Cheng, L., Liu, G., 2013e. LcSAIN1, a novel salt-induced gene from sheepgrass, confers salt stress tolerance in transgenic Arabidopsis and rice. Plant \& Cell Physiology 54, 1172-1185.

Li, Y., Wang, Q., Li, X., Xiao, X., Sun, F., Wang, C., Hu, W., Feng, Z., Chang, J., Chen, M., Wang, Y., Li, K., Yang, G., He, G., 2012b. Coexpression of the high molecular weight glutenin subunit $1 \mathrm{Ax} 1$ and puroindoline improves dough mixing properties in durum wheat (Triticum turgidum L. ssp. durum). PLoS One 7:e50057. 
1426

1427

1428

1429

1430

1431

1432

1433

1434

1435

1436

1437

1438

1439

1440

1441

1442

1443

1444

1445

1446

1447

1448

1449

Lipkie, T.E., De Moura, F.F., Zhao, Z.Y., Albertsen, M.C., Che, P., Glassman, K., Ferruzzi, M.G., 2013. Bioaccessibility of carotenoids from transgenic provitamin A biofortified sorghum. Journal of Agricultural and Food Chemistry 61, 5764-5771.

Liu, A.L., Zou, J., Liu, C.F., Zhou, X.Y., Zhang, X.W., Luo, G.Y., Chen, X.B., 2013a. Overexpression of $O s H s f A 7$ enhanced salt and drought tolerance in transgenic rice. BMB Reports 46, 31-36.

Liu, H.L., Yin, Z.J., Xiao, L., Xu, Y.N., Qu, L.Q., 2012. Identification and evaluation of $\omega-3$ fatty acid desaturase genes for hyperfortifying $\alpha$-linolenic acid in transgenic rice seed. Journal of Experimental Botany 63, 3279-3287.

Liu, X., Yang, L., Zhou, X., Zhou, M., Lu, Y., Ma, L., Ma, H., Zhang, Z., 2013b. Transgenic wheat expressing Thinopyrum intermedium MYB transcription factor TiMYB2R-1 shows enhanced resistance to the take-all disease. Journal of Experimental Botany $64,2243-2253$.

Liu, X., Zhai, S., Zhao, Y., Sun, B., Liu, C., Yang, A., Zhang, J., 2013c. Overexpression of the phosphatidylinositol synthase gene $(Z m P I S)$ conferring drought stress tolerance by altering membrane lipid composition and increasing ABA synthesis in maize. Plant Cell \& Environment 36, 1037-1055.

Long, X., Liu, Q., Chan, M., Wang, Q., Sun, S.S., 2013. Metabolic engineering and profiling of rice with increased lysine. Plant Biotechnol Journal 11, 490-501.

Loureiro, I., Escorial, M.C., González, Á., Chueca, M.C., 2012. Pollen-mediated gene flow in wheat (Triticum aestivum L.) in a semiarid field environment in Spain. Transgenic Research 21, 1329-1339.

Lovegrove, A., Wilkinson, M.D., Freeman, J., Pellny, T.K., Tosi, P., Saulnier, L., Shewry, P.R., Mitchell, R.A., 2013. RNAi suppression of genes in glycosyl transferase 
1450

1451

1452

1453

1454

1455

1456

1457

1458

1459

1460

1461

1462

1463

1464

1465

1466

1467

1468

1469

1470

1471

1472

1473

families 43 and 47 in wheat starchy endosperm causes large decreases in arabinoxylan content. Plant Physiology [Epub ahead of print]

Loza-Rubio, E., Rojas-Anaya, E., López, J., Olivera-Flores, M.T., Gómez-Lim, M., TapiaPérez, G., 2012. Induction of a protective immune response to rabies virus in sheep after oral immunization with transgenic maize, expressing the rabies virus glycoprotein. Vaccine 30, 5551-556.

Lu, Y., Li, Y., Zhang, J., Xiao, Y., Yue, Y., Duan, L., Zhang, M., Li, Z., 2013.

Overexpression of Arabidopsis molybdenum cofactor sulfurase gene confers drought tolerance in maize (Zea mays L.). PLoS One 8, e52126.

Lupi, R., Denery-Papini, S., Rogniaux, H., Lafiandra, D., Rizzi, C., De Carli, M., MoneretVautrin, D.A., Masci, S., Larré, C., 2013. How much does transgenesis affect wheat allergenicity?: Assessment in two GM lines over-expressing endogenous genes. Journal of Proteomics 80, 281-291.

Lupwayi, N.Z., Blackshaw, R.E., 2013. Soil microbial properties in Bt (Bacillus thuringiensis) corn cropping systems. Applied Soil Ecology 63, 127-133.

Lusser, M., Parisi, C., Plan, D., Rodriguez-Cerezo, E., 2011. New plant breeding techniques. State of the art and prospects for commercial development. JRC European Commission. 184 pp.

Ma, Q., Gao, C., Zhang, J., Zhao, L., Hao, W., Ji, C., 2013. Detection of transgenic and endogenous plant DNA fragments and proteins in the digesta, blood, tissues, and eggs of laying hens fed with phytase transgenic corn. PLoS One 8, e61138.

Magnusdottir, A., Vidarsson, H., Björnsson, J.M., Orvar, B.L., 2013. Barley grains for the production of endotoxin-free growth factors. Trends Biotechnology doi:pii: S01677799(13)00140-6. 10.1016/j.tibtech.2013.06.002. [Epub ahead of print] 
1474

1475

1476

1477

1478

1479

1480

1481

1482

1483

1484

1485

1486

1487

1488

1489

1490

1491

1492

1493

1494

1495

1496

1497

Manmathan, H., Shaner, D., Snelling, J., Tisserat, N., Lapitan, N., 2013. Virus-induced gene silencing of Arabidopsis thaliana gene homologues in wheat identifies genes conferring improved drought tolerance. Journal of Experimental Botany 64, 13811392.

Masip, G., Sabalza, M., Pérez-Massot, E., Banakar, R., Cebrian, D., Twyman, R.M., Capell, T., Albajes, R., Christou, P., 2013. Paradoxical EU agricultural policies on genetically engineered crops. Trends in Plant Science 18, 312-324.

Masuda, H., Ishimaru, Y., Aung, M.S., Kobayashi, T., Kakei, Y., Takahashi, M., Higuchi, K., Nakanishi, H., Nishizawa, N.K., 2012. Iron biofortification in rice by the introduction of multiple genes involved in iron nutrition. Scientific Reports 2, 543.

Masuda, H., Kobayashi, T., Ishimaru, Y., Takahashi, M., Aung, M.S., Nakanishi, H., Mori, S., Nishizawa N.K., 2013. Iron-biofortification in rice by the introduction of three barley genes participated in mugineic acid biosynthesis with soybean ferritin gene. Frontiers in Plant Science 4, 132.

Mather, D.W., Knight, J.G., Insch, A., Holdsworth, D.K., Ermen, D.F., Breitbarth, T., 2012. Social stigma and consumer benefits. Trade-offs in adoption of genetically modified foods. Science Communication 34, 487-519.

Meyer, J.B., Song-Wilson, Y., Foetzki, A., Luginbühl, C., Winzeler, M., Kneubühler, Y., Matasci, C., Mascher-Frutschi, F., Kalinina, O., Boller, T., Keel, C., Maurhofer, M., 2013. Does wheat genetically modified for disease resistance affect root-colonizing pseudomonads and arbuscular mycorrhizal fungi? PLoS One 8, e53825.

Miao, J., Wu, Y., Xu, W., Hu, L., Yu, Z., Xu, Q., 2011. The impact of transgenic wheat expressing GNA (snowdrop lectin) on the aphids Sitobion avenae, Schizaphis graminum, and Rhopalosiphum padi. Environmental Entomology 40, 743-748. 
1498

1499

1500

1501

1502

1503

1504

1505

1506

1507

1508

Mielby, H., Sandøe, P., Lassen, J., 2013. The role of scientific knowledge in shaping public attitudes to GM technologies. Public Understanding of Science 22, 155-168.

Mieog, J.C., Howitt, C.A., Ral, J-P., 2013. Fast-tracking development of homozygous transgenic cereal lines using a simple and highly flexible real-time PCR assay. BMC Plant Biology 13, 71.

Morell, M.K., 2012. New cereal value chain: from seed to sewage. Cereal Foods World 57, 44-49.

Mumm, R.H., 2013. A look at product development with genetically modified crops: examples from maize. Journal of Agricultural and Food Chemistry DOI: 10.1021/jf400685y [Epub ahead of print]

Nahampun, H.N., Lee, C.J., Jane, J.L., Wang, K., 2013. Ectopic expression of bacterial amylopullulanase enhances bioethanol production from maize grain. Plant Cell Reports DOI 10.1007/s00299-013-1453-y [Epub ahead of print]

Nandy, S., Srivastava, V., 2012. Marker-free site-specific gene integration in rice based on the use of two recombination systems. Plant Biotechnology Journal 10, 904-912.

Naqvi, S., Zhu, C., Farre, G., Ramessar, K., Bassie, L., Breitenbach, J., Conesa, D., Ros, G., Sandmann, G., Capell, T., Christou, P., 2009. Transgenic multivitamin corn through biofortification of endosperm with three vitamins representing three distinct metabolic pathways. Proceedings of the National Academy of Sciences of the United States of America 106, 7762-7767.

Narva, K.E., Siegfried, B.D., Storer, N.P., 2013. Transgenic approaches to western corn rootworm control. Advances in Biochemical Engineering/Biotechnology DOI 10.1007/10_2013_195 [Epub ahead of print]

Neal, A.L., Geraki, K., Borg, S., Quinn, P., Mosselmans, J.F., Brinch-Pedersen, H., Shewry, P.R., 2013. Iron and zinc complexation in wild-type and ferritin-expressing wheat 
grain: implications for mineral transport into developing grain. Journal of Biological Inorganic Chemistry 18, 557-570.

Nekrasov, V., Staskawicz, B., Weigel, D., Jones, J.D.G., Kamoun, S., 2013. Targeted mutagenesis in the model plant Nicotiana benthamiana using Cas9 RNA-guided endonuclease. Nature Biotechnology 31, 691-693.

Nemeth, C., Freeman, J., Jones, H.D., Sparks, C., Pellny, T.K., Wilkinson, M.D., Dunwell, J., Andersson, A.A.M., Åman, P., Guillon, F., Saulnier, L., Mitchell, R.A.C. and Shewry, P.R., 2010. Down-regulation of the CSLF6 gene results in decreased $(1,3 ; 1,4)-\beta$-D-glucan in endosperm of wheat. Plant Physiology 152, 1209-1218.

Nguyen, H.C., Hoefgen, R., Hesse, H., 2012. Improving the nutritive value of rice seeds: elevation of cysteine and methionine contents in rice plants by ectopic expression of a bacterial serine acetyltransferase. Journal of Experimental Botany 63, 5991-6001.

Nguyen, T.X., Sticklen, M., 2013. Barley HVA1 gene confers drought and salt tolerance in transgenic maize (Zea mays L.). Advances in Crop Science and Technology 1:105 doi :10.4172/acst.1000105.

Ogo, Y., Ozawa, K., Ishimaru, T., Murayama, T., Takaiwa, F., 2013. Transgenic rice seed synthesizing diverse flavonoids at high levels: a new platform for flavonoid production with associated health benefits. Plant Biotechnology Journal 11, 734746.

Okeno, J.A., Wolt, J.D., Misra, M.K., Rodriguez, L., 2013. Africa's inevitable walk to genetically modified (GM) crops: opportunities and challenges for commercialization. New Biotechnology 30, 124-30.

Oraby, H., Ahmad, R., 2012. Physiological and biochemical changes of CBF3 transgenic oat in response to salinity stress. Plant Science 185-186, 331-339. 
1547 Oszvald, M., Balázs, G., Pólya, S., Tömösközi, S., Appels, R., Békés, F., Tamás, L., 2013.

1548 Wheat storage proteins in transgenic rice endosperm. Journal of Agricultural and

$1549 \quad$ Food Chemistry DOI: 10.1021/jf402035n [Epub ahead of print]

1550 Paine, J., Shipton, C., Chaggar, S., Howells, R., Kennedy, M., Vernon, G., Wright, S.,

1551 Hinchliffe, E., Adams, J., Silverstone, A., Drake, R., 2005. Improving the

1552 nutritional value of Golden Rice through increased pro-vitamin A content. Nature

$1553 \quad$ Biotechnology 23, 482-487.

1554 Panwar, V., McCallum, B., Bakkeren, G., 2013. Endogenous silencing of Puccinia triticina

1555 pathogenicity genes through in planta-expressed sequences leads to the suppression

$1556 \quad$ of rust diseases on wheat. Plant Journal 73, 521-532.

1557 Park, S., Lee, D.E., Jang, H., Byeon, Y., Kim, Y.S., Back, K., 2013. Melatonin-rich

1558 transgenic rice plants exhibit resistance to herbicide-induced oxidative stress.

1559 Journal of Pineal Research 54, 258-263.

1560 Pauwels, K., Podevin, N., Breyer, D., Carroll, D., Herman, P., 2013. Engineering nucleases

1561 for gene targeting: safety and regulatory considerations. New Biotechnology doi:pii:

1562 S1871-6784(13)00094-0. 10.1016/j.nbt.2013.07.001. [Epub ahead of print]

1563 Pei, L., Wang, J., Li, K., Li, Y., Li, B., Gao, F., Yang, A., 2012. Overexpression of

$1564 \quad$ Thellungiella halophila $\mathrm{H}^{+}$-pyrophosphatase gene improves low phosphate

1565 tolerance in maize. PLoS One 7, e43501.

1566 Peng, X., Hu, Y., Tang, X., Zhou, P., Deng, X., Wang, H., Guo, Z., 2012. Constitutive

1567

expression of rice WRKY30 gene increases the endogenous jasmonic acid

1568

accumulation, PR gene expression and resistance to fungal pathogens in rice. Planta

1569 236, 1485-1498.

1570

Pérez-Massot, E., Banakar, R., Gómez-Galera, S., Zorrilla-López, U., Sanahuja, G., Arjó, G., 
1572

1573

1574

1575

1576

1577

1578

1579

1580

1581

1582

1583

1584

1585

1586

1587

1588

1589

1590

1591

1592

1593

1594

1595

Sabalza, M., Yuan, D., Bai, C., Bassie, L., Twyman, R.M., Capell, T., Christou, P., Zhu, C., 2013. The contribution of transgenic plants to better health through improved nutrition: opportunities and constraints. Genes \& Nutrition 8, 29-41.

Pila, J., 2009. Article 53(b) EPC: A challenge to the 'Novartis' theory of European patent history. Modern Law Review, Vol. 72, pp. 436-462, 2009; Oxford Legal Studies

Research Paper No. 21/2008. Available at SSRN: http://ssrn.com/abstract=1160191

Potrykus, I., 2012. “Golden Rice”, a GMO-product for public good, and the consequences of GE-regulation. Journal of Plant Biochemistry and Biotechnology 21, 68-75.

Privalle, L.S., Gillikin, N., Wandelt, C., 2013. Bringing a transgenic crop to market: where compositional analysis fits. Journal of Agricultural and Food Chemistry. DOI: 10.1021/jf400185q [Epub ahead of print]

Qin, J., Wang, Y., Xie Q., and Zhu, C., 2013. Optimization of regeneration system of tissue culture and transformation of $1 \mathrm{Dx} 5$ gene without markers in wheat. Advance Journal of Food Science and Technology 5, 9-13.

Ransom, J., Kanampiu, F., Gressel, J., De Groote, H., Burnet, M., Odhiambo, G., 2012. Herbicide applied to imidazolinone resistant-maize seed as a Striga control option for small-scale African farmers. Weed Science 60, 283-289.

Rao, J., Yang, L., Wang, C., Zhang, D., Shi, J., 2013. Digital gene expression analysis of mature seeds of transgenic maize overexpressing Aspergillus niger phyA2 and its non-transgenic counterpart. GM Crops and Food 4, 98-108.

Rawat, N., Neelam, K., Tiwari, V. K., Dhaliwal, H.S., 2013. Biofortification of cereals to overcome hidden hunger. Plant Breeding doi: 10.1111/pbr.12040 [Epub ahead of print] 
1596 Raybould, A., Higgins, L.S., Horak, M.J., Layton, R.J., Storer, N.P., De La Fuente, J.M.,

1597 Herman, R.A., 2013. Assessing the ecological risks from the persistence and spread

1598

1599

1600

1601

1602

1603

1604

1605

1606

1607

1608

1609

1610

1611

1612

1613

1614

1615

1616

1617

1618

1619

1620 of feral populations of insect-resistant transgenic maize. Transgenic Research 21, 655-664.

Redillas, M.C., Jeong, J.S., Kim, Y.S., Jung, H., Bang, S.W., Choi, Y.D., Ha, S.H., Reuzeau, C., Kim, J.K., 2012. The overexpression of OsNAC9 alters the root architecture of rice plants enhancing drought resistance and grain yield under field conditions. Plant Biotechnology Journal 10, 792-805.

Rieben, S., Kalinina, O., Schmid, B., Zeller, S.L., 2011. Gene flow in genetically modified wheat. PLoS One 6, e29730.

Risk, J.M, Selter, L.L., Krattinger, S.G., Viccars, L.A., Richardson, T.M., Buesing, G., Herren, G., Lagudah, E.S., Keller, B., 2012. Functional variability of the Lr34 durable resistance gene in transgenic wheat. Plant Biotechnology Journal 10, 477487.

Risk, J.M., Selter, L.L., Chauhan, H., Krattinger, S.G., Kumlehn, J., Hensel, G., Viccars, L.A., Richardson, T.M., Buesing, G., Troller, A., Lagudah, E.S., Keller, B., 2013. The wheat $L r 34$ gene provides resistance against multiple fungal pathogens in barley. Plant Biotechnology Journal doi: 10.1111/pbi.12077. [Epub ahead of print]

Robert, C.A., Erb, M., Hiltpold, I., Hibbard, B.E., Gaillard, M.D., Bilat, J., Degenhardt, J., Cambet-Petit-Jean, X., Turlings, T.C., Zwahlen, C., 2013. Genetically engineered maize plants reveal distinct costs and benefits of constitutive volatile emissions in the field. Plant Biotechnology Journal 11, 628-639.

Robertson, G.H., Blechl, A.E., Hurkman, W.J., Anderson, O.D., Cao, T.K., Tanaka, C.K., Gregorski, K.S., Orts, W.J., 2013. Physical characteristics of genetically altered wheat related to technological protein separation. Cereal Chemistry 90, 1-12. 
1621 Rodríguez-Entrena, M., Sayadi, S., 2013. Analyzing consumers' preferences towards GM

1622

1623

1624

1625

1626

1627

1628

1629

1630

1631

1632

1633

1634

1635

1636

1637

1638

1639

1640

1641

1642

1643

1644

1645 food in southern Spain. New Genetics and Society 32, 18-36.

Romeis, J., McLean, M.A., Shelton, A.M., 2013. When bad science makes good headlines: Bt maize and regulatory bans. Nature Biotechnology 31, 386-387.

Rong, W., Qi, L., Wang, J., Du, L., Xu, H., Wang, A., Zhang, Z., 2103. Expression of a potato antimicrobial peptide SN1 increases resistance to take-all pathogen Gaeumannomyces graminis var. tritici in transgenic wheat. Functional \& Integrative Genomics 13, 403-409.

Runo, S., Macharia, S., Alakonya, A., Machuka, J., Sinha, N., Scholes, J., 2012. Striga parasitizes transgenic hairy roots of Zea mays and provides a tool for studying plant-plant interactions. Plant Methods 8, 20.

Saad, A.S., Li, X., Li, H.P., Huang, T., Gao, C.S., Guo, M.W., Cheng, W., Zhao, G.Y., Liao, Y.C., 2013. A rice stress-responsive NAC gene enhances tolerance of transgenic wheat to drought and salt stresses. Plant Science 203-204, 33-40.

Sabalza, M., Madeira, L., van Dolleweerd, C., Ma, J.K., Capell, T., Christou, P., 2012. Functional characterization of the recombinant HIV-neutralizing monoclonal antibody 2F5 produced in maize seeds. Plant Molecular Biology 80, 477-488.

Saeki, M., Nishimura, T., Kaminuma, O., Suzuki, K., Takai, T., Mori, A., Takada, K., Takaiwa, F., Hiroi, T., 2012. Inhibition of allergen-induced airway inflammation by low-dose oral immunotherapy with transgenic rice seeds independently of immunoglobulin e synthesis. International Archives of Allergy and Immunology 158 Suppl 1, 66-69.

Saeki, M., Nishimura, T., Kaminuma, O., Mori, A., Hiroi, T., 2013. Oral immunotherapy for allergic diseases using transgenic rice seeds: current state and future prospects. International Archives of Allergy and Immunology 161 Suppl 2:164-169. 
1646 Saint Pierre, C., Crossa, J.L., Bonnett, D., Yamaguchi-Shinozaki, K., Reynolds, M.P., 2012.

1647

1648

1649

1650

1651

1652

1653

1654

1655

1656

1657

1658

1659

1660

1661

1662

1663

1664

1665

1666

1667

1668

1669

1670

Phenotyping transgenic wheat for drought resistance. Journal of Experimental Botany 63, 1799-1808.

Saintenac, C., Zhang, W., Salcedo, A., Rouse, M.N., Trick, H.N., Akhunov, E., Dubcovsky, J., 2013. Identification of wheat gene Sr35 that confers resistance to Ug99 stem rust race group. Science DOI:10.1126/science.1239022 [Epub ahead of print]

Sainz, M.B., 2009. Commercial cellulosic ethanol: The role of plant-expressed enzymes. In Vitro Cellular Developmental Biology - Plant 45, 314-329.

Sestili, F., Botticella, E., Proietti, G., Janni, M., D’Ovidio, R., Lafiandra, D., 2012. Amylose content is not affected by overexpression of the $W x-B 1$ gene in durum wheat. Plant Breeding 131, 700-706.

Sestili, F., Paoletti, F., Botticella, E., Masci, S., Saletti, R., Muccilli, V., Lafiandra, D., 2013. Comparative proteomic analysis of kernel proteins of two high amylose transgenic durum wheat lines obtained by biolistic and Agrobacterium-mediated transformations. Journal of Cereal Science 58, 15-22.

Shan, Q., Wang, Y., Li, J., Zhang, Y., Chen, K., Liang, Z., Zhang, K., Liu, J., Xi, J.J., Qiu, JL., Gao, C., 2013. Targeted genome modification of crop plants using a CRISPR-Cas system. Nature Biotechnology 31, 686-688.

Shen, B., Sun, X., Zuo, X., Shilling, T., Apgar, J., Ross, M., Bougri, O., Samoylov, V., Parker, M., Hancock, E., Lucero, H., Gray, B., Ekborg, N.A., Zhang, D., Johnson, J.C., Lazar, G., Raab, R.M., 2012. Engineering a thermoregulated intein-modified xylanase into maize for consolidated lignocellulosic biomass processing. Nature Biotechnology 30, 1131-1136.

Shi, G., Chavas, J.P., Lauer, J., 2013. Commercialized transgenic traits, maize productivity and yield risk. Nature Biotechnology 31, 111-114. 
1671

1672

1673

1674

1675

1676

1677

1678

1679

1680

1681

1682

1683

1684

1685

1686

1687

1688

1689

1690

1691

1692

1693

1694

Shimizu, T., Lin, F., Hasegawa, M., Nojiri, H., Yamane, H., Okada, K., 2012a. The potential bioproduction of the pharmaceutical agent sakuranetin, a flavonoid phytoalexin in rice. Bioengineered 3, 352-357.

Shimizu, T., Nakazono-Nagaoka, E., Akita, F., Wei, T., Sasaya, T., Omura, T., UeharaIchiki, T., 2012b. Hairpin RNA derived from the gene for Pns9, a viroplasm matrix protein of Rice gall dwarf virus, confers strong resistance to virus infection in transgenic rice plants. Journal of Biotechnology 157, 421-427.

Shimizu, T., Ogamino, T., Hiraguri, A., Nakazono-Nagaoka, E., Uehara-Ichiki, T., Nakajima, M., Akutsu, K., Omura, T., Sasaya, T., 2013. Strong resistance against rice grassy stunt virus is induced in transgenic rice plants expressing double-stranded RNA of the viral genes for nucleocapsid or movement proteins as targets for RNA interference. Phytopathology 103, 513-519.

Speiser, B., Stolze, M., Oehen, B., Gessler, C., Weibel, F.P., Bravin, E., Kilchenmann, A., Widmer, A., Charles, R., Lang, A., Stamm, C., Triloff, P., Tamm, L., 2013. Sustainability assessment of GM crops in a Swiss agricultural context. Agronomy for Sustainable Development 33, 21-61.

Soltész, A., Vágújfalvi, A., Rizza, F., Kerepesi, I., Galiba, G., Cattivelli, L., Coraggio, I., Crosatti, C., 2011. The rice Osmyb4 gene enhances tolerance to frost and improves germination under unfavourable conditions in transgenic barley plants. Journal of Applied Genetics 53, 133-143.

Soltész, A., Smedley, M., Vashegyi, I., Galiba, G., Harwood, W., Vágújfalvi, A., 2013. Transgenic barley lines prove the involvement of TaCBF14 and TaCBF15 in the cold acclimation process and in frost tolerance. Journal of Experimental Botany 64, 1849-1862. 
1695

1696

1697

1698

1699

1700

1701

1702

1703

1704

1705

1706

1707

1708

1709

1710

1711

1712

1713

1714

1715

1716

1717

1718

Srivastava, S.P., 2013. Science, technology development and threat to human rights: a need to reformulate legal foundations. International Journal of Private Law 6, 88-98.

Storozhenko, S., De Brouwer, V., Volckaert, M., Navarrete, O., Blancquaert, D., Zhang, G.F., Lambert, W., Van Der Straeten, D., 2007. Folate fortification of rice by metabolic engineering. Nature Biotechnology 25, 1277-1279.

Sun, C.X., Yuan, F., Zhang, Y.L., Cui, Z.B., Chen, Z.H., Chen, L.J., Wu, Z.J., 2013. Unintended effects of genetic transformation on photosynthetic gas exchange, leaf reflectance and plant growth properties in barley (Hordeum vulgare L.). Photosynthetica 51, 22-32.

Sun, S., Gu, M., Cao, Y., Huang, X., Zhang, X., Ai, P., Zhao, J., Fan, X., Xu, G., 2012. A constitutive expressed phosphate transporter, OsPht1;1, modulates phosphate uptake and translocation in phosphate-replete rice. Plant Physiology 159, 15711581.

Tabashnik, B.E., Gould, F., 2012. Delaying corn rootworm resistance to Bt corn. Journal of Economic Entomology 105, 767-776.

Tabashnik, B.E., Brévault, T., Carrière, Y., 2013. Insect resistance to Bt crops: lessons from the first billion acres. Nature Biotechnology 31, 510-521.

Takahashi, R., Ishimaru, Y., Shimo, H., Ogo, Y., Senoura, T., Nishizawa, N.K., Nakanishi, H., 2012. The OsHMA2 transporter is involved in root-to-shoot translocation of $\mathrm{Zn}$ and Cd in rice. Plant Cell and Environment 35, 1948-1957.

Takaiwa, F., 2013. Update on the use of transgenic rice seeds in oral immunotherapy. Immunotherapy 5, 301-312.

Tamás-Nyitrai, C., Jones, H.D., Tamás, L., 2012. Biolistic- and Agrobacterium-mediated transformation protocols for wheat. Methods in Molecular Biology 877, 357-384. 
1719 Tang, M., He, X., Luo, Y., Ma, L., Tang, X., Huang, K., 2013. Nutritional assessment of

1720

1721

1722

1723

1724

1725

1726

1727

1728

1729

1730

1731

1732

1733

1734

1735

1736

1737

1738

1739

1740

1741

1742

1743 transgenic lysine-rich maize compared with conventional quality protein maize. Journal of the Science of Food and Agriculture 93, 1049-1054.

Tian, J.C., Chen, Y., Li, Z.L., Li, K., Chen, M., Peng, Y.F., Hu, C., Shelton, A.M., Ye, G.Y., 2012. Transgenic Cry1 Ab rice does not impact ecological fitness and predation of a generalist spider. PLoS One 7, e35164.

Todaka, D., Nakashima, K., Maruyama, K., Kidokoro, S., Osakabe, Y., Ito, Y., Matsukura, S., Fujita, Y., Yoshiwara, K., Ohme-Takagi, M., Kojima, M., Sakakibara, H., Shinozaki, K., Yamaguchi-Shinozaki, K., 2012. Rice phytochrome-interacting factor-like protein OsPIL1 functions as a key regulator of internode elongation and induces a morphological response to drought stress. Proceedings of the National Academy of Sciences of the United States of America 109, 15947-15952.

Tovkach, A., Ryan, P.R., Richardson, A.E., Lewis, D.C., Rathjen, T.M., Ramesh, S, Tyerman, S.D., Delhaize, E., 2013. Transposon-mediated alteration of TaMATE1B expression in wheat confers constitutive citrate efflux from root apices. Plant Physiology 161, 880-892.

Tuncel, A., Okita, T.W., 2013. Improving starch yield in cereals by over-expression of ADPglucose pyrophosphorylase: Expectations and unanticipated outcomes. Plant Science http://dx.doi.org/10.1016/j.plantsci.2013.06.009 [Epub ahead of print]

van der Linde, K., Hemetsberger, C., Kastner, C., Kaschani, F., van der Hoorn, R.A., Kumlehn, J., Doehlemann, G., 2012. A maize cystatin suppresses host immunity by inhibiting apoplastic cysteine proteases. Plant Cell 24, 1285-1300.

Várallyay, E., Giczey, G., Burgyán, J., 2012. Virus-induced gene silencing of Mlo genes induces powdery mildew resistance in Triticum aestivum. Archives of Virology $157,1345-1350$. 
1744

1745

1746

1747

1748

1749

1750

1751

1752

1753

1754

1755

1756

1757

1758

1759

1760

1761

1762

1763

1764

1765

1766

1767

1768

Velasco, A.G., Kowalchuk, G.A., Mañero, F.J.G., Ramos, B., Yergeau, E., García, J.A.L., 2013. Increased microbial activity and nitrogen mineralization coupled to changes in microbial community structure in the rhizosphere of Bt corn. Applied Soil Ecology 68, 46-56.

von Burg, S., Álvarez-Alfageme, F., Romeis, J., 2012. Indirect effect of a transgenic wheat on aphids through enhanced powdery mildew resistance. PLoS One 7, e46333.

Wakasa, Y., Ozawa, K., Takaiwa, F., 2012. Agrobacterium-mediated co-transformation of rice using two selectable marker genes derived from rice genome components. Plant Cell Reports 31, 2075-2084.

Wang, J., Sun, J., Miao, J., Guo, J., Shi, Z., He, M., Chen, Y., Zhao, X., Li, B., Han, F., Tong, Y., Li, Z., 2013a. A phosphate starvation response regulator Ta-PHRl is involved in phosphate signalling and increases grain yield in wheat. Annals of Botany 111, $1139-1153$.

Wang, L., Zheng, J., Luo, Y., Xu, T., Zhang, Q., Zhang, L., Xu, M., Wan, J., Wang, M.B., Zhang, C., Fan, Y., 2013b. Construction of a genomewide RNAi mutant library in rice. Plant Biotechnol Journal doi: 10.1111/pbi.12093. [Epub ahead of print]

Wang, M., Liu, C., Li, S., Zhu, D., Zhao, Q., Yu, J., 2013c. Improved nutritive quality and salt resistance in transgenic maize by simultaneously overexpression of a natural lysine-rich protein gene, $S B g L R$, and an ERF transcription factor gene, TSRF1. International Journal of Molecular Science 14, 9459-9474.

Wang, S., Takahashi, H., Kajiura, H., Kawakatsu, T., Fujiyama, K., Takaiwa, F., 2013d. Transgenic rice seeds accumulating recombinant hypoallergenic birch pollen allergen Bet v 1 generate giant protein bodies. Plant \& Cell Physiology 54, 917-933.

Wang, S., Tang, C.H., Zhang, J.M., Wang, X.Q., 2013e. The effect of dietary supplementation with phytase transgenic maize and different concentrations of non- 
1769

1770

1771

1772

1773

1774

1775

1776

1777

1778

1779

1780

1781

1782

1783

1784

1785

1786

1787

1788

1789

1790

1791

1792

1793

phytate phosphorus on the performance of laying hens. British Poultry Science 54, 466-470.

Wang, Y., Shen, Q., Jiang, Y., Song, Y., Fang, L., Xiao, S., Chen, H., 2012. Immunogenicity of foot-and-mouth disease virus structural polyprotein P1 expressed in transgenic rice. Journal of Virology Methods 181, 12-17.

Wendt, T., Holm, P.B., Starker, C.G., Christian, M., Voytas, D.F., Brinch-Pedersen, H., Holme, I.B., 2013. TAL effector nucleases induce mutations at a pre-selected location in the genome of primary barley transformants. Plant Molecular Biology DOI 10.1007/s11103-013-0078-4 [Epub ahead of print]

Wenefrida, I., Utomo, H.S., Linscombe, S.D., 2013. Review of mutational breeding and genetic engineering approaches to the development of high protein content in the grain. Journal of Agricultural and Food Chemistry DOI: 10.1021/jf4016812 [Epub ahead of print]

Wirth, J., Poletti, S., Aeschlimann, B., Yakandawala, N., Drosse, B., Osorio, S., Tohge, T., Fernie, A.R., Günther, D., Gruissem, W., Sautter, C., 2009. Rice endosperm iron biofortification by targeted and synergistic action of nicotianamine synthase and ferritin. Plant Biotechnology Journal 7, 631-644.

Xia, L., Ma, Y., He, Y., Jones, H.D., 2012. GM wheat development in China: current status and challenges to commercialization. Journal of Experimental Botany 63, 17851790.

Xu, C., Cheng, Z., Yu, W., 2012a. Construction of rice mini-chromosomes by telomeremediated chromosomal truncation. Plant Journal 70, 1070-1079.

Xu, J., Dolan, M.C., Medrano, G., Cramer, C.L., Weathers, P.J., 2012b. Green factory: plants as bioproduction platforms for recombinant proteins. Biotechnology Advances 30, $1171-1184$. 
1794 Xu, J., Li, M., Chen, L., Wu, G., Li, H., 2012c. Rapid generation of rice mutants via the 1795 dominant negative suppression of the mismatch repair protein OsPMS1. Theoretical 1796 and Applied Genetics 125, 975-986.

1797

Xu, J., Cao, J., Cao, D., Zhao, T., Huang, X., Zhang, P., Luan, F., 2013a. Flanking sequence determination and event-specific detection of genetically modified wheat B73-6-1. Acta Biochimica et Biophysica Sinica 45, 416-421.

Xu, X., Zhang, Y., Meng, Q., Meng, K., Zhang, W., Zhou, X., Luo, H., Chen R., Yang, P., Yao, B., 2013b. Overexpression of a fungal $\beta$-mannanase from Bispora sp. MEY-1

1802 in maize seeds and enzyme characterization. PLoS One 8, e56146.

1803

Yang, L., Hirose, S., Suzuki, K., Hiroi, T., Takaiwa, F., 2012a. Expression of hypoallergenic 1804 Der f 2 derivatives with altered intramolecular disulphide bonds induces the formation of novel ER-derived protein bodies in transgenic rice seeds. Journal of yield in rice seed is enhanced by specific suppression of endogenous seed proteins at the same deposit site. Plant Biotechnology Journal 10, 1035-1045. Experimental Botany 63, 2947-2959.

Yang, L., Hirose, S., Takahashi, H., Kawakatsu, T., Takaiwa, F., 2012b. Recombinant protein

Yang, X., Wang, F., Su, J., Lu, B.R., 2012c. Limited fitness advantages of crop-weed hybrid progeny containing insect-resistant transgenes $(B t / C p T I)$ in transgenic rice field. PLoS One 7, e41220.

Ye, X., Al-Babili, S., Klöti, A., Zhang, J., Lucca, P., Beyer, P., Potrykus, I., 2000. Engineering the provitamin A ( $\beta$-carotene) biosynthetic pathway into (carotenoidfree) rice endosperm. Science 287, 303-305. of transposon Ac/Ds-induced chromosome rearrangements in rice. Theoretical and Applied Genetics 125, 1449-1462. 
1819

1820

1821

1822

1823

1824

1825

1826

1827

1828

1829

1830

1831

1832

1833

1834

1835

1836

1837

1838

1839

1840

1841

1842
Zaplin, E.S., Liu, Q., Li, Z., Butardo, V.M., Blanchard, C.L., Rahman, S., 2013. Production of high oleic rice grains by suppressing the expression of the OsFAD2-1 gene. Functional Plant Biology http://dx.doi.org/10.1071/FP12301 [in press]

Zeller, S.L., Kalinina, O., Flynn, D.F.B., Schmid, B., 2012. Mixtures of genetically modified wheat lines outperform monocultures. Ecological Applications 22, 1817-1826.

Zeller, S.L., Kalinina, O., Schmid, B., 2013. Costs of resistance to fungal pathogens in genetically modified wheat. Journal of Plant Ecology 6, 92-100.

Zhang, D., Lee, H.F., Pettit, S.C., Zaro, J.L., Huang, N., Shen W.C., 2013. Characterization of transferrin receptor-mediated endocytosis and cellular iron delivery of recombinant human serum transferrin from rice (Oryza sativa L.). BMC Biotechnology 12, 92.

Zhang, G.Y., Liu, R.R., Xu, G., Zhang, P., Li, Y., Tang, K.X., Liang, G.H., Liu, Q.Q., 2013a. Increased $\alpha$-tocotrienol content in seeds of transgenic rice overexpressing Arabidopsis $\gamma$-tocopherol methyltransferase. Transgenic Research 22, 89-99.

Zhang, L., Shi, J., Jiang, D., Stupak, J., Ou, J., Qiu, Q., An, N., Li, J., Yang, D., $2013 b$. Expression and characterization of recombinant human alpha-antitrypsin in transgenic rice seed. Journal of Biotechnology 164, 300-308.

Zhang, Q., Zhang, W., Lin, C., Xu, X., Shen, Z., 2012a. Expression of an Acidothermus cellulolyticus endoglucanase in transgenic rice seeds. Protein Expression and Purification 82, 279-283.

Zhang, S., Haider, I., Kohlen, W., Jiang, L., Bouwmeester, H., Meijer, A.H., Schluepmann, H., Liu, C.M., Ouwerkerk, P.B., 2012b. Function of the HD-Zip I gene Oshox22 in ABA-mediated drought and salt tolerances in rice. Plant Molecular Biology 80, $571-585$. 
1843

1844

1845

1846

1847

1848

1849

1850

1851

1852

1853

1854

1855

1856

1857

1858

1859

1860

1861

1862

1863

1864

1865

1866

1867

Zhang, X, Wang, J, Huang, J, Lan, H, Wang, C, Yin, C, Wu, Y, Tang, H, Qian, Q, Li, J, Zhang, H., 2012c. Rare allele of $O s P P K L 1$ associated with grain length causes extra-large grain and a significant yield increase in rice. Proceedings of the National Academy of Sciences of the United States of America 109, 21534-21539.

Zhang, X.X., Yu, H., Wang, X.H., Li, X.Z., Zhu, Y.P., Li, H.X., Luo, S.J., Yuan, Z.G., 2013c. Protective efficacy against Chlamydophila psittaci by oral immunization based on transgenic rice expressing MOMP in mice. Vaccine 31, 698-703.

Zhang, Y-H.P., 2013. Next generation biorefineries will solve the food, biofuels, and environmental trilemma in the energy-food-water nexus. Energy Science \& Engineering 1, 27-41.

Zhang, Z, Liu, X, Wang, X, Zhou, M, Zhou, X, Ye, X, Wei, X., 2012d. An R2R3 MYB transcription factor in wheat, TaPIMP1, mediates host resistance to Bipolaris sorokiniana and drought stresses through regulation of defense- and stress-related genes. New Phytologist 196, 1155-1170.

Zhou, G., Delhaize, E., Zhou, M., Ryan, P.R., 2013. The barley MATE gene, HvAACT1, increases citrate efflux and $\mathrm{Al}^{3+}$ tolerance when expressed in wheat and barley. Annals of Botany 112, 603-612.

Zhou, X.H., Dong, Y., Wang, Y., Xiao, X., Xu, Y., Xu, B., Li, X., Wei, X.S., Liu, Q.Q., 2012a. A three generation study with high-lysine transgenic rice in Sprague-Dawley rats. Food Chemistry and Toxicology 50, 1902-1910.

Zhou, Y., Yuan, Y., Yuan, F., Wang, M., Zhong, H., Gu, M., Liang, G., 2012b. RNAidirected down-regulation of RSV results in increased resistance in rice (Oryza sativa L.). Biotechnology Letters 34, 965-972.

Zhu, C., Naqvi, S., Breitenbach, J., Sandman, G., Christou, P., Capell, T., 2008. Combinatorial genetic transformation generated a library of metabolic phenotypes 
for the carotenoid pathway in maize. Proceedings of the National Academy of Sciences of the United States of America 105, 18232-18237.

Zhu, L., Gu, M., Meng, X., Cheung, S.C., Yu, H., Huang, J., Sun, Y., Shi, Y., Liu, Q., 2012a. High-amylose rice improves indices of animal health in normal and diabetic rats. Plant Biotechnology Journal 10, 353-362.

Zhu, X., Li, Z., Xu, H., Zhou, M., Du, L., Zhang, Z., 2012b. Overexpression of wheat lipid transfer protein gene TaLTP5 increases resistances to Cochliobolus sativus and Fusarium graminearum in transgenic wheat. Functional and Integrative Genomics $12,481-488$.

Ziemienowicz, A., Shim, Y.S., Matsuoka, A., Eudes, F., Kovalchuk, I., 2012. A novel method of transgene delivery into triticale plants using the Agrobacterium transferred DNA-derived nano-complex. Plant Physiology 158, 1503-1513.

Zukoff, S.N., Bailey, W.C., Ellersieck, M.R., Hibbard B.E., 2012. Western corn rootworm larval movement in SmartStax seed blend scenarios. Journal of Economic Entomology 105, 1248-1260. 
Table 1. Global area, production, yield and contribution to the human diet for major cereal crops

\begin{tabular}{|c|c|c|c|c|c|c|c|c|c|c|}
\hline & \multicolumn{5}{|c|}{2010 (FAOSTAT) } & \multicolumn{5}{|c|}{2009 (FAOSTAT) } \\
\hline & \multicolumn{2}{|l|}{ Area } & \multicolumn{2}{|c|}{ Production } & Yield & \multicolumn{3}{|c|}{ Energy } & \multicolumn{2}{|c|}{ Protein } \\
\hline & Mha & $\%$ & MT & $\%$ & Tonne & $\mathrm{kcal} /$ & $\%$ & & $\mathrm{~g} /$ & $\%$ \\
\hline Wheat & 217 & 32 & 651 & 27 & 3.0 & 532 & 18.8 & & 16.2 & 20.4 \\
\hline Maize & 162 & 24 & 844 & 35 & 5.2 & 141 & 5.0 & & 3.4 & 2.3 \\
\hline Rice & 154 & 23 & 672 & 28 & 4.4 & 536 & 18.9 & & 10.1 & 12.7 \\
\hline Barley & 48 & 7 & 123 & 5 & 2.6 & 7 & 0.2 & & 0.2 & 0.3 \\
\hline Sorghum & 41 & 6 & 56 & 2 & 1.4 & 32 & 1.1 & & 1.0 & 1.3 \\
\hline Total & 683 & 100 & 2432 & 100 & 3.6 & 1248 & 44 & 30.9 & 38.6 & \\
\hline
\end{tabular}

Adapted from Wheat Initiative (2013) 
Table 2. Evolution of wheat yield over 10-year periods since 1960 (FAO) and projected needs for 2050

\begin{tabular}{|c|c|c|c|c|c|}
\hline Period & $\begin{array}{l}\text { Mean area } \\
\text { harvested/yr }\end{array}$ & $\begin{array}{l}\text { Mean } \\
\text { production/yr }\end{array}$ & $\begin{array}{l}\text { Mean production } \\
\text { increase/yr (\%) }\end{array}$ & $\begin{array}{l}\text { Mean yield } \\
\text { (t/ha) }\end{array}$ & $\begin{array}{l}\text { Mean yield } \\
\text { increase/yr }\end{array}$ \\
\hline & (Mha) & (Mt) & & & $(\%)$ \\
\hline $1961-1970$ & 213 & 278 & & & \\
\hline $1971-1980$ & 225 & 388 & 3.9 & 1.7 & 3.2 \\
\hline 1981-1990 & 229 & 509 & 3.1 & 2.2 & 2.9 \\
\hline $1991-2000$ & 220 & 571 & 1.2 & 2.6 & 1.7 \\
\hline $2001-2010$ & 216 & 622 & 0.9 & 2.9 & 1.1 \\
\hline 2050 (target) & 220 & 1045 & 1.7 & 4.75 & 1.6 \\
\hline
\end{tabular}

Adapted from Wheat Initiative (2013) 
Table 3. Field trials of GM wheat and barley in Australia: Applications and licences for Dealings involving Intentional Release (DIR) into the environment

Number Organisation Description Crop(s) Trait Date

DIR117

CSIRO

grain composition, wheat,

nutrition,

Mar 2013

nutrient utilisation

barley

yield

DIR112

CSIRO

grain composition,

wheat,

nutrition,

Mar 2012

nutrient utilisation

barley

yield

DIR111

CSIRO

grain composition,

wheat,

yield,

Feb 2012

nutrient utilisation

barley

disease, stress

DIR102

abiotic stress

wheat,

yield, stress

Jun 2010

barley

DIR100

CSIRO

drought, heat

wheat

yield, stress

Jun 2010

DIR099

CSIRO

grain composition,

wheat,

nutrition,

Mar 2013

DIR094

CSIRO

nutrient utilisation

barley

yield

nutrient utilisation

wheat,

yield

Jul 2009

barley

DIR093

\section{CSIRO}

grain starch

wheat,

nutrition

Jun 2009

barley 


\begin{tabular}{|c|c|c|c|c|c|}
\hline DIR092 & CSIRO & grain composition & wheat & $\begin{array}{l}\text { nutrition, } \\
\text { processing }\end{array}$ & May 2009 \\
\hline DIR080 & $\begin{array}{l}\text { Vict. Dept. } \\
\text { Prim. Indust. }\end{array}$ & drought & wheat & abiotic stress & Jun 2008 \\
\hline DIR077 & Uni. Adelaide & stress, glucan & $\begin{array}{l}\text { wheat, } \\
\text { barley }\end{array}$ & $\begin{array}{l}\text { stress, } \\
\text { nutrition }\end{array}$ & Jun 2008 \\
\hline DIR071 & $\begin{array}{l}\text { Vict. Dept. } \\
\text { Prim. Indust. }\end{array}$ & drought & wheat & abiotic stress & Jun 2007 \\
\hline DIR061 & Grain Biotech & salt tolerance & wheat & stress tolerance & Withdrawn \\
\hline DIR054 & CSIRO & grain starch & & nutrition & Apr 2005 \\
\hline DIR054 & Grain Biotech & salt tolerance & & stress tolerance & Apr 2005 \\
\hline
\end{tabular}

Summary of data from the Office of the Gene Regulator. Available at:http://www.ogtr.gov.au/internet/ogtr/publishing.nsf/Content/ir-1 
Table 4. Transgenic cereals with enhanced content of vitamins and minerals

Nutrient Species $\quad$ Genes used Total increase (fold References

increase over WT)

\begin{tabular}{|c|c|c|c|c|}
\hline \multirow[t]{7}{*}{ Vitamin A } & Maize & PacrtB, PacrtI & $33.6 \mu \mathrm{g} / \mathrm{g}$ DW (34) & Aluru et al., 2008 \\
\hline & Maize & Zmpsy1, PacrtI, PcrtW, & $146.7 \mu \mathrm{g} / \mathrm{g}$ DW (133) & Zhu et al., 2008 \\
\hline & & Gllycb & & \\
\hline & Maize & Zmpsyl, PacrtI & $163.2 \mu \mathrm{g} / \mathrm{g}$ DW (112) & Naqvi et al., 2009 \\
\hline & Wheat & Zmpsyl, $\mathrm{Pa}$ & $4.96 \mu \mathrm{g} / \mathrm{g}$ DW (10.8) & Cong et al., 2009 \\
\hline & Rice & Nppsyl, EucrtI & $1.6 \mu \mathrm{g} / \mathrm{g}$ & Ye et al., 2000 \\
\hline & Rice & Zmppsyl, EucrtI & $37 \mu \mathrm{g} / \mathrm{g}(23)$ & Paine et al., 2005 \\
\hline Vitamin C & Maize & Osdhar & $110 \mu \mathrm{g} / \mathrm{g}$ DW (6) & Naqvi et al., 2009 \\
\hline \multirow[t]{2}{*}{ Vitamin E } & Rice & $H P P D$ & & Farré et al., 2012 \\
\hline & & $\gamma$-TMT & & Zhang et al., 2013a \\
\hline \multirow[t]{2}{*}{ Folic acid } & $\mathrm{Bic}$ & Atgtpchi, Atadcs & $38.3 \mathrm{nmol} / \mathrm{g}(100)$ & Storozhenko et al., \\
\hline & & & & 2007 \\
\hline \multirow[t]{6}{*}{ Iron } & Rice & Osnas2 & $19 \mu \mathrm{g} / \mathrm{g} D W$ in & Johnson et al., \\
\hline & & & polished seeds (4.2) & 2011 \\
\hline & Rice & Gm ferritin, Af phytase, & $7 \mu \mathrm{g} / \mathrm{g}$ DW in & Wirth et al., 2009 \\
\hline & & Osnasl & polished seeds (4-6.3) & \\
\hline & Rice & Activation tagging & $32 \mu \mathrm{g} / \mathrm{g}$ DW in & Lee et al., 2009 \\
\hline & & of Osnas3 & dehusked seeds (2.9) & \\
\hline
\end{tabular}




\begin{tabular}{|c|c|c|c|c|}
\hline & \multirow{2}{*}{ Maize } & Gm ferritin and & $30 \mu \mathrm{g} / \mathrm{g}$ DW in whole & Drakakaki et al., \\
\hline & & Af phytase & seed (2) & 2005 \\
\hline & \multirow[t]{2}{*}{ Rice } & \multirow[t]{2}{*}{ Ferritin } & $7 \mu \mathrm{g} / \mathrm{g} D W$ in & Masuda et al., 2012, \\
\hline & & & polished seed (6) & 2013 \\
\hline \multirow[t]{5}{*}{ Zinc } & \multirow[t]{2}{*}{ Rice } & Activation tagging & $40-45 \mu \mathrm{g} / \mathrm{g}$ DW in & Lee et al., 2011 \\
\hline & & of Osnas 2 & polished seeds (2.9) & \\
\hline & Rice & Osnas2 & $52-76 \mu \mathrm{g} / \mathrm{g}$ DW in & Johnson et al., \\
\hline & \multirow[t]{2}{*}{ Rice } & \multicolumn{2}{|c|}{ Gm ferritin, Af phytase, $35 \mu \mathrm{g} / \mathrm{g}$ DW } & Wirth et al., 2009 \\
\hline & & Osnas1 & polished seeds (1.6) & \\
\hline
\end{tabular}

Data adapted from Pérez-Massot et al. (2012) and other sources. 
Table 5. Summary of selected field trials of GM cereals in the EU

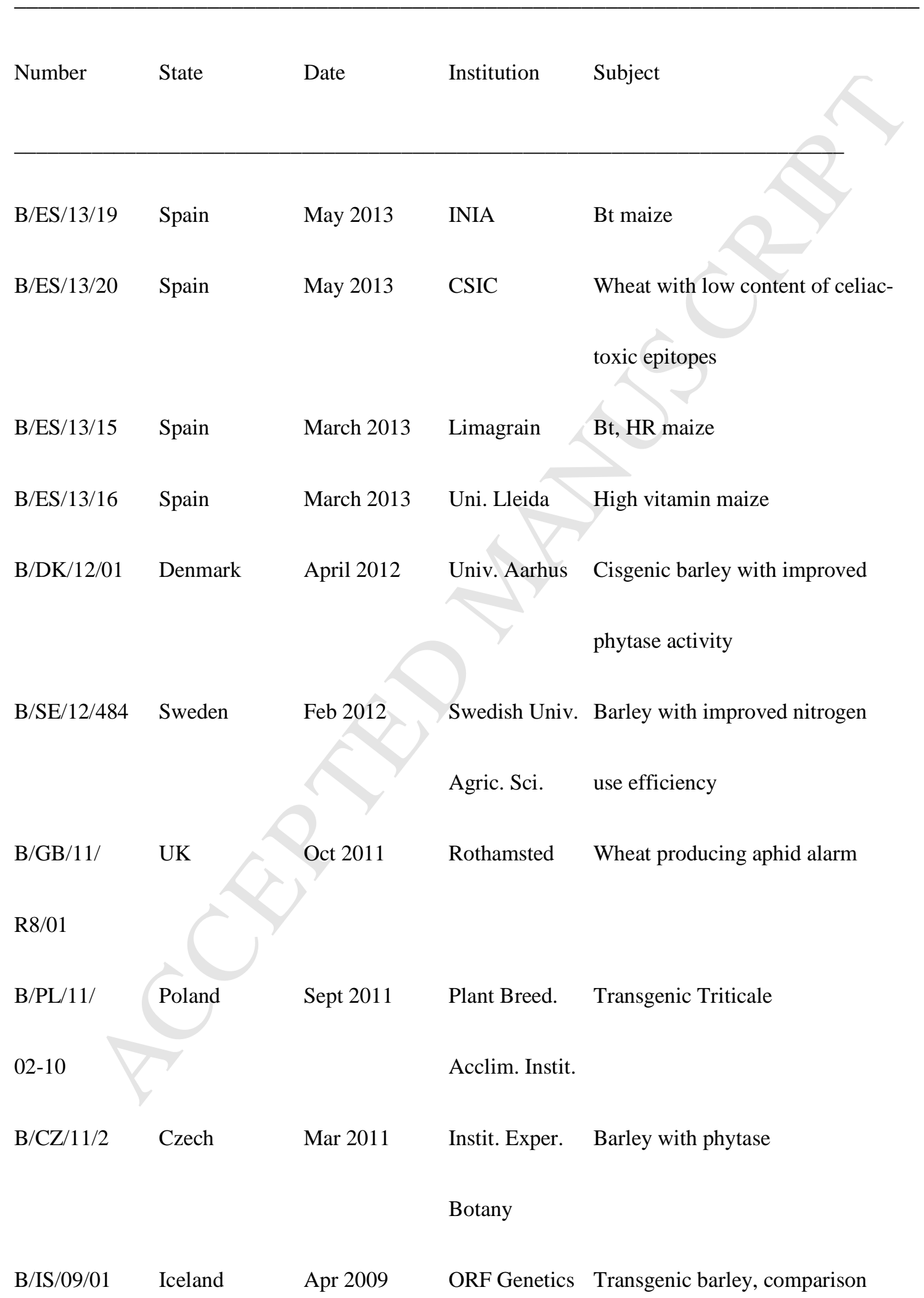


of processing quality

Available from JRC database (http://gmoinfo.jrc.ec.europa.eu/gmp_browse.aspx) 
Table 6. Summary of selected USA granted patents (a) and patent applications (b) relating to GM cereals; data from 2013. Data are from the USPTO (http://www.uspto.gov/patents/process/search/index.jsp).

(a)

Number Date Inventor Subject

8,440,886 14 May Lundquist et al. Transgenic maize

8,440,881 14 May $\quad$ Park et al. Genes for yield

8,431,775 30 April Hegstad et al. knottedl gene

8,431,402 30 April Vasudevan et al. Sorghum regeneration

8,426,704 23 April Hirel et al. Glutamine synthetase

8,426,677 23 April Yu et al. $\quad$ GA20 oxidase

8,426,676 23 April Oswald et al. Pyruvate kinases

8,420,893 16 April $>$ Gordon-Kamm et al. AP2 domain transcript. factor

8,415,526 9 April McGonigle Artificial microRNAs

8,404,933 26 March Chen et al. Herbicide resistance gene

8,404,930 26 March Wu et al. Monocot transformation

8,404,929 26 March Gruis et al. Reducing gene expression 
(b)

\begin{tabular}{|c|c|c|c|}
\hline 20130133111 & 23 May & Lyznik et al. & MAPKKK genes to improve yield \\
\hline 20130133101 & 23 May & Rodiuc et al & Phytosulfokines and pathogen resistance \\
\hline 20130125266 & 16 May & Hiei et al. & Agrobacterium, barley transformation \\
\hline 20130125264 & 16 May & Frankard et al. & Genes for yield \\
\hline 20130125258 & 16 May & Emmanuel et al. & Genes for yield \\
\hline 20130117894 & 9 May & Frohberg et al. & Starch synthase \\
\hline 20130117888 & 9 May & Sanz Molinero et al. & Genes for yield \\
\hline 20130116124 & 9 May & Fernandez et al. & Bacterial volatiles and starch \\
\hline 20130111634 & 2 May & Kurek et al. & Artificial microRNAs \\
\hline 20130111632 & 2 May & Champion et al. & Jasmonic acid \\
\hline 20130111620 & $2 \mathrm{Ma}$ & D'Halluin et al. & Meganucleases \\
\hline 20130111618 & 2 May & Mankin et al. & Herbicide tolerance \\
\hline
\end{tabular}

